\title{
Effects of in vitro insulin and 2,4-thiazolidinedione on the function of neutrophils harvested from blood of cows in different physiological states
}

\author{
X. S. Revelo and M. R. Waldron ${ }^{1}$ \\ Division of Animal Sciences, University of Missouri-Columbia, Columbia 65211
}

\begin{abstract}
Neutrophils [polymorphonuclear neutrophilic leukocytes (PMNL)] were isolated from 26 Holstein cows in different physiological states ( $12 \pm 1.7 \mathrm{~d}$ prepartum, $\mathrm{n}$ $=8 ; 7 \pm 0 \mathrm{~d}$ postpartum, $\mathrm{n}=9 ; 253 \pm 25.2 \mathrm{~d}$ postpartum, $\mathrm{n}=9$ ) and incubated in vitro for $120 \mathrm{~min}$ in a factorial arrangement of treatments with $0,1.5$, or $15 \mathrm{ng} / \mathrm{mL}$ of bovine insulin and 0 or $300 \mu \mathrm{g} / \mathrm{mL}$ of the peroxisome proliferator-activated receptor- $\gamma$ ligand 2,4-thiazolidinedione (TZD). Following the incubations, PMNL functional assays were performed to determine treatment effects on proxies for total, extracellular, and intracellular generation of reactive oxygen species (ROS), neutrophil extracellular trap formation, and phagocytic killing abilities. The ROS production of PMNL collected from cows at $7 \mathrm{~d}$ postpartum was reduced compared with that of PMNL from midlactation and prepartum cows, but neutrophil extracellular trap expression was 23 and $36 \%$ greater in PMNL from prepartum cows compared with that in PMNL from midlactation and postpartum cows, respectively. Insulin had no effect on PMNL functional assay results. In contrast, TZD inhibited a measurement of total ROS production by $89 \%$, increased extracellular superoxide generation by $43 \%$, but had no effect on the intracellular ROS measured. Interestingly, TZD did not alter the ability of the PMNL to release neutrophil extracellular traps and engulf or kill Staphylococcus aureus. These findings suggest a possible anti-inflammatory effect of TZD that may result in reduced extracellular oxidative damage with maintenance of PMNL antimicrobial activity.
\end{abstract}

Key words: neutrophil, immunosuppression, insulin, thiazolidinedione

\section{INTRODUCTION}

The periparturient dairy cow is more susceptible to infectious diseases in part due to a period of immunosuppression that occurs for several weeks around the

Received November 18, 2009.

Accepted May 3, 2010.

${ }^{1}$ Corresponding author: waldronm@missouri.edu time of calving (Mallard et al., 1998). As an example, the number of first cases of clinical mastitis was greater during the first week of lactation compared with those detected from the second week onward (Wilson et al., 2004). Shuster et al. (1996) challenged cows with an intramammary infusion of Escherichia coli and reported that periparturient cows had more severe clinical signs of mastitis as well as a more rapid bacterial growth after $10 \mathrm{~h}$ of inoculation compared with midlactation animals. Despite considerable progress in the last $25 \mathrm{yr}$ in the understanding of the biology of the periparturient cow, the incidence and severity of the most important infectious disease has remained unchanged (LeBlanc et al., 2006). A recent survey by the National Animal Health Monitoring Service reported that clinical mastitis is prevalent in $16.5 \%$ of the cows in the United States (USDA, 2008). Furthermore, this survey revealed that of the total number of cows that are permanently removed from the herd, $23 \%$ are culled because of mastitis or udder-related problems.

During an IMI, patrolling macrophages recognize the pathogen and trigger an inflammatory response resulting in the migration of PMNL or neutrophils from circulation to the site of infection. Thus, during the early stages of the insult, neutrophils are the predominant leukocyte present in the gland, accounting for up to $91 \%$ of the total leukocyte population (Saad and Ostensson, 1990). Neutrophils play a key role in the resolution of mastitis and have been the focus of intense research (Paape et al., 2003). These PMNL, by means of their toll-like receptors and other pattern-recognition receptors, bind and engulf opsonized bacteria in a process known as phagocytosis. Subsequently, PMNL use several killing mechanisms such as generation and release of potent oxidants [e.g., intracellular and extracellular reactive oxygen species (ROS)] and antimicrobial enzymes and peptides (Paape et al., 2002). Neutrophils are also capable of mixing these toxic compounds with their own DNA and histones and releasing structures termed neutrophil extracellular traps (NET) into the extracellular matrix, where the pathogens are physically trapped and destroyed (Brinkmann et al., 2004).

The total number and function of neutrophils are reduced during the periparturient period (Kehrli et 
al., 1989; Cai et al., 1994; Detilleux et al., 1995), but the physiological mechanisms responsible for these decreases remain unclear (Paape et al., 2002). Remarkably, there is a coincidence between this period of reduced neutrophil function and the periparturient fall of plasma insulin together with the onset of insulin resistance during late gestation as discussed by Bell and Bauman (1997). Moreover, there is evidence that insulin can regulate neutrophil function in humans. For instance, neutrophils collected from healthy individuals had improved chemotaxis, phagocytosis, and bactericidal ability after the subjects received a 4-h insulin infusion under strict euglycemia, relative to the neutrophils collected before the infusion (Walrand et al., 2004). However, the effects of this hormone on neutrophil function have not been investigated in dairy cows, despite the fact that neutrophils isolated from dairy heifers (Nielsen et al., 2003) and multiparous cows [S. Kato (University of Vermont, Burlington) and M. R. Waldron; unpublished observation] express insulin receptors. Relative to insulin function, the synthetic peroxisome proliferator-activated receptor (PPAR)- $\gamma$ ligand 2,4 thiazolidinedione (TZD) has been shown to restore insulin response in steers with insulin resistance induced by recombinant tumor necrosis $\alpha$ (Kushibiki et al., 2001). Peroxisome proliferator-activated receptor- $\gamma$ is a member of the nuclear receptor family highly expressed in adipose tissue and the immune system that upon activation can regulate adipocyte differentiation, stimulate insulin action, regulate lipid metabolism, and affect inflammatory processes (Houseknecht et al., 2002). Therefore, we hypothesized that periparturient cows have reduced neutrophil function compared with midlactation animals and that incubation of PMNL with insulin or the PPAR- $\gamma$ ligand TZD would improve PMNL functionality as assessed by the production and release of ROS, NET formation, and their phagocytotic and killing ability.

\section{MATERIALS AND METHODS}

\section{Animal Procedures}

The use and care of all animals were approved by The University of Vermont Animal Care and Use Committee. Twenty-six multiparous Holstein cows entering second or greater lactation were used in this experiment. All cows were free of obvious clinical infection or inflammation, and their rectal temperatures were less than $39.5^{\circ} \mathrm{C}$. Individual milk samples were collected the day of the experiments, and SCC were determined using a DeLaval cell counter (DeLaval International AB, Tumba, Sweden). Milk SCC were not different between midlactation and postpartum cows $(181 \pm 54$ and 145 $\pm 57 \times 10^{3} \mathrm{SCC} / \mathrm{mL}$, respectively; $\left.P>0.20\right)$. Blood $(80 \mathrm{~mL})$ was collected via coccygeal vessel puncture into evacuated tubes containing acid-citrate dextrose (Vacutainer, Becton Dickinson, Franklin Lakes, NJ), inverted 3 times, and stored on ice until laboratory processing $(<45 \mathrm{~min})$. Samples were taken from cows $12 \pm 1.7 \mathrm{~d}$ before calving $(\mathrm{n}=8), 7 \mathrm{~d}$ postpartum $(\mathrm{n}$ $=9)$, and during midlactation $(\mathrm{n}=9 ; 253 \pm 25.2 \mathrm{~d}$ postpartum, $138 \pm 9.9 \mathrm{~d}$ pregnant) to evaluate the differential effects of physiologic state and in vitro insulin and TZD incubation on blood neutrophil function. All functional assays were performed simultaneously on the same day for any given cow.

\section{Reagents}

Percoll was obtained from GE Healthcare BioSciences Corp. (Piscataway, NJ). Bovine insulin at a concentration of $10 \mathrm{mg} / \mathrm{mL}$ in a $25 \mathrm{~m} M$ HEPES, $\mathrm{pH}$ 8.2, solution and Ionomycin from Streptomyces conglobatus were obtained from Sigma Chemical Co. (St. Louis, MO). The TZD (Sigma Chemical Co.) was prepared as a $100 \mathrm{mg} / \mathrm{mL}$ stock solution in dimethyl sulfoxide (DMSO). Luminol (5-amino-2,3-dihydro1,4-phthalazinedione; Sigma Chemical Co.), methyl cypridina luciferin analog [MCLA; 2-methyl-6-(4methoxyphenyl)-3,7dihydroimidazol[1,2-a]pyrazin-3one hydrochloride; Sigma Chemical Co.], and phorbol 12-myristate,13-acetate (PMA; Sigma Chemical Co.) were prepared as $89.4 \mathrm{mM}, 1371.1 \mu M$, and 162.12 $\mu M$ stock solutions, respectively, in DMSO. The 5-(6)-chloromethyl-2',7'-dichlorodihydrofluorescein diacetate acetyl ester $\left(\mathbf{C M}-\mathbf{H}_{2} \mathbf{D C F D A}\right.$; Invitrogen Co., Eugene, OR) was prepared as $1730.7 \mu M$ stock solution in DMSO. Sytox Orange nucleic acid stain was obtained from Invitrogen Co. as a $5 \mathrm{mM}$ solution in DMSO. All stock solutions were stored at $-20^{\circ} \mathrm{C}$. All working solutions, cell suspensions, and reactions were prepared using sterile calcium- and magnesium-free Hanks' Balanced Salt Solution (CMF-HBSS; Sigma Chemical Co.) or RPMI-1640 (GIBCO, Grand Island, $\mathrm{NY}$ ) and prewarmed to $37^{\circ} \mathrm{C}$ immediately before their use in the assays. In our in vitro cellular system, CMFHBSS and RPMI-1640 (Table 1) were used to maintain a balanced environment (intra- and extracellular osmolarity, $\mathrm{pH},\left[\mathrm{O}_{2}\right]$, and temperature) and provide the cells with water and inorganic ions essential for normal cell metabolism. The use of HBSS as a buffering medium during PMNL-chemiluminescence (CL) assays results in maximal light emission and cell activation compared with PBS and Tris (Freitas et al., 2009). 


\section{Isolation of Bovine Neutrophils}

Neutrophils were isolated using procedures modified from Weber et al. (2001) as validated in our laboratory. Blood $(10 \mathrm{~mL})$ was aliquotted into $50-\mathrm{mL}$ polypropylene conical tubes (Corning Inc., Corning, NY) and centrifuged at $1,000 \times g$ for $20 \mathrm{~min}$ at $4^{\circ} \mathrm{C}$ to separate plasma from the cell pack. The plasma was discarded, and the remaining cells were suspended in $35 \mathrm{~mL}$ of ice-cold PBS. The suspension was gently pipetted down the side of a $50-\mathrm{mL}$ polypropylene conical tube containing $10 \mathrm{~mL}$ of $1.084 \mathrm{~g} / \mathrm{mL}$ Percoll. The cells were then subjected to gradient centrifugation $(400 \times g$ for 40 min at $22^{\circ} \mathrm{C}$ ). The supernatant, mononuclear cell layer, and Percoll were aseptically aspirated and discarded. The pellet (PMNL and erythrocytes) was retained, and erythrocytes were lysed by hypotonic shock. For this procedure, 2 volumes of an ice-cold $10.56 \mathrm{mM} \mathrm{Na}_{2} \mathrm{HPO}_{4}$, $2.67 \mathrm{mM} \mathrm{NaH} \mathrm{PO}_{4}$ solution were added to 1 volume of cell suspension, and the solution was mixed by gentle aspiration and inversion. Tonicity was restored by the addition of 1 volume of a $10.56 \mathrm{mM} \mathrm{Na}{ }_{2} \mathrm{HPO}_{4}, 2.67 \mathrm{mM}$ $\mathrm{NaH}_{2} \mathrm{PO}_{4}, 0.43 M \mathrm{NaCl}$ solution. The cell solution was then centrifuged $(500 \times g)$ for 4 min at $4^{\circ} \mathrm{C}$, and the pellet was washed twice by resuspension in $35 \mathrm{~mL}$ of CMF-HBSS and recentrifugation $(500 \times g$ for $3 \mathrm{~min}$ at $\left.4^{\circ} \mathrm{C}\right)$. Cell viability and differential cell counts were determined using light microscopy by trypan blue (Sigma Chemical Co.) exclusion and Giemsa-stained smears, respectively. Purity of PMNL was $>95 \%$ and viability $>97 \%$. Cells were suspended either in CMF-HBSS or in RPMI-1640, the concentration of cells was adjusted for every assay, and the suspensions were kept at $4^{\circ} \mathrm{C}$ until use in functional assays.

\section{Insulin and TZD Incubations}

Incubations and functional assays were performed in white-walled, clear-bottomed 96-well microplates (Corning, Costar Inc., NY), except for the killingphagocytosis assay, which was conducted in 5-mL polystyrene round-bottomed tubes (Becton Dickinson Labware). For all the assays, working solutions of insulin, TZD, or insulin and TZD in CMF-HBSS or RPMI-1640 $+2 \%$ heat-inactivated fetal bovine serum (NET assay) were pipetted into the wells or tubes to reach final concentrations of $0,1.5$, or $15 \mathrm{ng} / \mathrm{mL}$ of insulin, alone or in combination with $300 \mu \mathrm{g} / \mathrm{mL}$ of TZD. Suspensions of $2 \times 10^{5}$ (luminol assay; final volume $200 \mu \mathrm{L} /$ well), 4 $\times 10^{5}$ (MCLA and CM- $\mathrm{H}_{2} \mathrm{DCFDA}$ assays; final volume $150 \mu \mathrm{L} /$ well $), 5 \times 10^{5}$ (NET assay; final volume 100 $\mu \mathrm{L} /$ well), and $2 \times 10^{5}$ neutrophils (killing-phagocytosis assay; final volume 1,000 $\mu \mathrm{L} /$ tube) in CMF-HBSS or RPMI-1640 were added to the treatment solutions. The
Table 1. Composition of calcium- and magnesium-free Hanks' Balanced Salt Solution (CMF-HBSS) and RPMI- $1640^{1}$ used in the vitro cellular systems

\begin{tabular}{lcc}
\hline & \multicolumn{2}{c}{ Medium } \\
\cline { 2 - 3 } Component & $\begin{array}{c}\text { CMF-HBSS } \\
(\mathrm{g} / \mathrm{L})\end{array}$ & $\begin{array}{c}\text { RPMI-1640 } \\
(\mathrm{g} / \mathrm{L})\end{array}$ \\
\hline $\mathrm{KCl}$ & 0.40 & 0.40 \\
$\mathrm{KH}_{2} \mathrm{PO}_{4}$ & 0.06 & - \\
$\mathrm{NaHCO}_{3}$ & 0.35 & 2.00 \\
$\mathrm{NaCl}_{\mathrm{Na}} \mathrm{HPO}_{4}$ & 8.00 & 6.00 \\
$\mathrm{Ca}\left(\mathrm{NO}_{3}\right)_{2} 4 \mathrm{H}_{2} \mathrm{O}$ & 0.05 & 0.80 \\
$\mathrm{MgSO}_{4}$ & - & 0.10 \\
$\mathrm{D}-\mathrm{glucose}$ & - & 0.05 \\
\hline
\end{tabular}

${ }^{1}$ RPMI-1640, GIBCO, Grand Island, NY.

plates and tubes were then incubated with lids in a humidified incubator $\left(37^{\circ} \mathrm{C}, 5 \% \mathrm{CO}_{2}\right)$ for 120 min while being gently shaken. After incubation, the cell suspensions were mixed by aspiration, and the functional assays were performed.

\section{Luminol CL Assay}

After incubation with insulin and TZD, a proxy of the total neutrophil ROS production was immediately assessed by a luminol CL assay as described by Rinaldi et al. (2007) with some modifications validated in our laboratory. Luminol is a cell-permeable compound that reacts with superoxide $\left(\mathrm{O}_{2}^{-}\right)$, hydroxyl radical $\left(\mathrm{OH}^{-}\right)$, hydrogen peroxide $\left(\mathrm{H}_{2} \mathrm{O}_{2}\right)$, peroxynitrite $\left(\mathrm{ONOO}^{-}\right)$, and hypochlorous acid (HClO; Rinaldi et al., 2007). Although the derived luminescence product of these reactions in the presence of luminol is not all-inclusive, it is a satisfactory indicator of the intracellular and extracellular ROS generation by the PMNL. Twenty microliters of $5 \mathrm{mM}$ 5-amino-2,3-dihydro-1,4-phthalazinedione (luminol) and $20 \mu \mathrm{L}$ of either $400 \mathrm{nM}$ PMA (stimulated cells) or HBSS (control) were added to all wells. All reactions were then adjusted to $200 \mu \mathrm{L}$ using CMF-HBSS. Chemiluminescence was measured every 5 or $10 \mathrm{~min}$ for $190 \mathrm{~min}$ with a Synergy HT plate reader (BioTek Instruments Inc., Winooski, VT). All reactions were carried out in quadruplicate. Background values, defined as the mean CL values of unactivated PMNL, were subtracted from all readings.

\section{MCLA CL Assay}

After incubation, the extracellular neutrophil superoxide anion radical $\left(\mathrm{O}_{2}^{-}\right)$production was measured by a MCLA CL assay. The specificity of this probe for $\mathrm{O}_{2}{ }^{-}$ was confirmed by Rinaldi et al. (2007), who reported that superoxide dismutase, the enzyme that catalyzes 
the conversion of $\mathrm{O}_{2}^{-}$to $\mathrm{H}_{2} \mathrm{O}_{2}$, completely abrogated the MCLA-dependent CL. Ten microliters of $2 \mu M$ MCLA and $30 \mu \mathrm{L}$ of either $400 \mathrm{n} M$ PMA (stimulated cells) or HBSS (control) were added to all wells. The reactions were then adjusted to a volume of $200 \mu \mathrm{L}$ using CMF-HBSS. The CL was measured every $10 \mathrm{~min}$ for 80 min with a Synergy HT plate reader (BioTek Instruments Inc.). Because MCLA is rapidly consumed, $10 \mu \mathrm{L}$ of $2 \mu M$ MCLA was added to each well immediately before each 10-min reading throughout the course of CL measurements. All reactions were carried out in quintuplicate. Background values, defined as the mean CL values of unactivated PMNL, were subtracted from all readings.

\section{CM- $\mathrm{H}_{2}$ DCFDA Fluorescence Assay}

A proxy for the intracellular neutrophil ROS production was assessed using the $\mathrm{CM}-\mathrm{H}_{2} \mathrm{DCFDA}$ fluorescence assay with some modifications. The cell-permeant probe CM- $\mathrm{H}_{2}$ DCFDA reacts only with ROS that are trapped inside the cell, including hydrogen peroxide $\left(\mathrm{H}_{2} \mathrm{O}_{2}\right)$, nitric oxide $(\mathrm{NO})$, and peroxynitrite anion $\left(\mathrm{ONOO}^{-}\right)$ (Rinaldi et al., 2007). After incubation, $10 \mu \mathrm{L}$ of 200 $\mu M \mathrm{CM}-\mathrm{H}_{2} \mathrm{DCFDA}$ and $30 \mu \mathrm{L}$ of either $400 \mathrm{n} M$ PMA (stimulated cells) or HBSS (control) were added to all wells. All reactions were then adjusted to $200 \mu \mathrm{L}$ using CMF-HBSS. Fluorescence was measured every $10 \mathrm{~min}$ for $200 \mathrm{~min}$, except between min 30 and 70 when it was measured every 5 min, with a Synergy HT plate reader (BioTek Instruments Inc.) at an excitation wavelength of $485 \mathrm{~nm}$ and an emission wavelength of $528 \mathrm{~nm}$. All reactions were carried out in quadruplicate. Background values, defined as the mean fluorescence values of unactivated PMNL, were subtracted from all readings.

\section{NET Assay}

Neutrophil extracellular trap formation was quantified using Sytox Orange as described by Lippolis et al. (2006b) with some modifications. After PMNL incubation with treatments in 96-well plates for $120 \mathrm{~min}, 20$ $\mu \mathrm{L}$ of PMA and $20 \mu \mathrm{L}$ of ionomycin were added to the stimulated set of wells to obtain final concentrations of $10 \mathrm{ng} / \mathrm{mL}$ and $1 \mu M$, respectively. Forty microliters of RPMI-1640 + $2 \%$ heat-inactivated fetal bovine serum were added to the control wells. Subsequently, the plates were centrifuged $\left(650 \times g\right.$ for $10 \mathrm{~min}$ at $\left.23^{\circ} \mathrm{C}\right)$ and incubated $\left(37^{\circ} \mathrm{C}\right.$ and $5 \% \mathrm{CO}_{2}$ for $\left.60 \mathrm{~min}\right)$. After incubation, supernatant from the plates was removed, and the wells were stained and protected from light with $50 \mu \mathrm{L}$ of $5 \mu M$ Sytox Orange in CMF-HBSS (10 min at room temperature). The stain was poured off and the wells washed once with $100 \mu \mathrm{L}$ of CMF-HBSS. All reactions were performed in sixtuplicate. A Synergy HT plate reader (BioTek Instruments Inc.) was used to detect fluorescence with an excitation wavelength of $530 \mathrm{~nm}$ and emission wavelength of $580 \mathrm{~nm}$. Background values, defined as the mean fluorescence values of unactivated PMNL, were subtracted from all readings.

\section{Killing and Phagocytosis Assay}

The phagocytosis and killing assay was performed as described by Rinaldi et al. (2006) with modifications validated in our laboratory. Staphylococcus aureus strain 305 (American Type Culture Collection, Manassas, VA) was inoculated on a blood agar plate (Northeast Laboratory Services Inc., Winslow, ME) and incubated overnight at $37^{\circ} \mathrm{C}$. Ten colonies were transferred from the plate to a sterile tube containing $10 \mathrm{~mL}$ of brainheart infusion broth (Becton Dickinson Diagnostic Systems Inc.) and incubated overnight at $37^{\circ} \mathrm{C}$ at 0.54 $\times g$ in an orbital shaker (model G2, New Brunswick Scientific Inc., Edison, NJ). After the overnight incubation, the tube was placed in an ice-water bath and subsequently mixed using a vortex mixer. One hundred microliters from the culture was serially diluted in PBS, and $100 \mu \mathrm{L}$ of the resulting dilutions was spread on blood agar plates. The stock culture was maintained at $4^{\circ} \mathrm{C}$, and the plates were incubated overnight at $37^{\circ} \mathrm{C}$ to determine the concentration $(\mathrm{cfu} / \mathrm{mL})$ of the stock culture based on the colony counts of the spread plates. Immediately before the initiation of the phagocytosis and killing assay, the stock culture was placed on ice and diluted in HBSS to yield a final concentration of 4 $\times 10^{7} \mathrm{cfu} / \mathrm{mL}$.

To assess PMNL phagocytosis and killing, $200 \mu \mathrm{L}$ of Staph. aureus $\left(8 \times 10^{6} \mathrm{cfu}\right)$ and $400 \mu \mathrm{L}$ of pooled, heatinactivated bovine serum were added to sterile tubes with or without $2 \times 10^{6}$ PMNL previously incubated with the insulin and TZD treatments $(1.4 \mathrm{~mL})$. The ratio of bacteria to PMNL was 4:1. The samples were placed on a tube rotator for $60 \mathrm{~min}$ at $37^{\circ} \mathrm{C}$. All reactions were performed in duplicate. To determine the percentage of PMNL containing phagocytosed bacteria and the actual number of phagocytosed bacteria per PMNL, a $50-\mu \mathrm{L}$ aliquot of each reaction was used to prepare a smear that was stained with Giemsa stain. The first 100 PMNL encountered in the field of view of a light microscope were scored as either positive or negative for intracellular bacteria. For those PMNL scored as positive, the number of intracellular bacteria was enumerated.

To evaluate whether insulin and TZD incubations affected the bactericidal activity of PMNL, $1.95 \mathrm{~mL}$ of the remaining reaction was placed in ice and sonicated with a sonic dismembrator (model 100, Thermo Fisher 
Scientific Inc., Pittsburgh, PA) at a power setting of 1 for $15 \mathrm{~s}$. Rupture of the PMNL was verified by microscopic examination. Sonication did not affect bacterial viability (Rinaldi et al., 2007; X. S. Revelo and M. R. Waldron, unpublished observation). A $100-\mu \mathrm{L}$ aliquot from each sonicated reaction was serially diluted in PBS, and $100-\mu \mathrm{L}$ quantities of the resulting dilutions were spread on blood agar plates. The plates were incubated overnight at $37^{\circ} \mathrm{C}$ and the colonies enumerated. The percentage of bacteria killed was determined by calculating the difference in the number of bacteria incubated in the absence and presence of PMNL and dividing this difference by the number of bacteria incubated in the absence of PMNL.

\section{Statistical Analysis}

The experiment was conducted as a completely randomized design with a factorial arrangement of treatments (insulin, TZD, and physiological state) applied to the incubation well or tube within cow. Data was analyzed by ANOVA as a mixed model using the mixed procedure of SAS (2001). The variables in the model statement included animal, the treatments, and their interactions. For the luminol-, MCLA-, and $\mathrm{CM}_{-} \mathrm{H}_{2} \mathrm{D}-$ CFDA-based assays involving multiple measurements of CL or fluorescence over time, the area under the curve (AUC) was calculated from plotted data points for each experimental condition using the expand procedure of SAS with cubic spline interpolation and the trapezoid rule (SAS, 2001). The analyzed area between the curves was generated using the least squares estimates for CL or fluorescence at each time point in the assay, and this area was used as the value tested for ANOVA. For the $\mathrm{CM}-\mathrm{H}_{2} \mathrm{DCFDA}$ assay, a mixed model ANOVA with repeated measures was also used as a more sensitive analysis of treatment differences than the calculation of AUC. Least squares means and standard errors were generated using the LSMeans statement in conjunction with the pdiff option of SAS (2001). Tukey's multiple comparison test was used to assess specific treatment differences for those variables shown to have significant overall treatment effects in the ANOVA. All reported means are the adjusted least squares means \pm standard error of the mean, and the significance was declared when $P<0.01$.

\section{RESULTS}

\section{ROS Production}

Changes in luminol-derived CL were evident $30 \mathrm{~min}$ after activation with PMA. For those cells incubated with $0,1.5$, or $15 \mathrm{ng} / \mathrm{mL}$ of insulin without TZD,
CL values peaked 100 min after activation and then decreased. In contrast, the luminol-derived CL values of PMNL treated with $300 \mu \mathrm{g} / \mathrm{mL}$ of TZD were only modestly increased from baseline with a peak at 70 min after activation and displayed a much more rapid decline back to baseline compared with insulin-only treatments or control wells (Figure 1A). To determine any differential effects of in vitro insulin and TZD treatment on PMNL, the AUC were calculated from these plotted data points. Insulin treatment had no effect on the luminol-dependent CL associated with total ROS production in PMA-stimulated cells; luminol-derived CL was not different between control and insulin-only treated wells (Figure 1B; insulin treatment effect, $P$ $>0.20$ ). Incubation of cells with $300 \mu \mathrm{g} / \mathrm{mL}$ of TZD inhibited total ROS by approximately $88.9 \%$ compared with control and insulin-only treated wells (Figure 1B; TZD treatment effect, $P<0.01$ ). The overall effect of physiological state on luminol-derived CL is presented in Figure 2. The luminol-derived CL of neutrophils isolated from postpartum cows was 37 and $32 \%$ less compared with that of midlactation and prepartum animals, respectively (physiological state effect, $P<$ 0.01). However, the luminol-derived CL of PMNL collected from midlactation cows was not different from that of PMNL isolated from prepartum cows (midlactation vs. prepartum, $P>0.20$ ). Furthermore, there was no insulin-by-physiological state interaction effect $(P$ $>0.20)$, but the magnitude of the reduction in the luminol-derived CL observed in postpartum cows relative to midlactation and prepartum cows with $0 \mu \mathrm{g} /$ $\mathrm{mL}$ TZD treatment was less than the magnitude of this reduction in PMNL incubated with $300 \mu \mathrm{g} / \mathrm{mL}$ of TZD (Figure 3; TZD-by-physiological state interaction effect, $P<0.01)$.

The MCLA-derived CL in all treatment and control groups peaked at the 21 min measurement time point after PMA activation and then declined. The PMNL treated with $300 \mu \mathrm{g} / \mathrm{mL}$ of TZD had a greater maximal response after cell stimulation, and this difference was maintained throughout the rest of the MCLA-derived CL measurements compared with insulin-only treatments or control wells (Figure 4A). To determine any differential effects of in vitro insulin and TZD treatment on PMNL, the AUC were calculated from these plotted data points. Insulin treatment had no effect $(P>0.20)$ relative to control wells on the MCLA-dependent CL associated with extracellular $\mathrm{O}_{2}^{-}$ROS production in PMA-stimulated cells (Figure 4B). In contrast, TZD enhanced the $\mathrm{O}_{2}^{-}$generation approximately $43 \%$ compared with control wells (Figure 4B; TZD treatment effect, $P<0.01$ ). Neutrophils from postpartum cows had a 42.9 and $36.6 \%$ lower MCLA-dependent CL compared with those from midlactation and prepartum ani- 
mals, respectively (Figure 5; physiological state effect, $P<0.01)$. The MCLA-derived CL of PMNL collected from midlactation cows was similar to that of PMNL isolated from prepartum cows (Figure 5; $P>0.20$ ). No interaction effects with either in vitro treatment or physiological state were evident for PMNL MCLAderived CL (all interactions, $P>0.20$ ).

Changes in $\mathrm{CM}-\mathrm{H}_{2} \mathrm{DCFDA}$-derived fluorescence were observed at $30 \mathrm{~min}$ after activation with PMA. The fluorescence values from the cells incubated with 300 $\mu \mathrm{g} / \mathrm{mL}$ of TZD increased and reached a plateau approximately $140 \mathrm{~min}$ after stimulation, whereas those of PMNL incubated with $0,1.5$, or $15 \mathrm{ng} / \mathrm{mL}$ of insulin without TZD continued to increase (Figure 6A). There was no effect of insulin or TZD on the intracellular ROS production based on calculated AUC (Figure 6B; insulin or TZD effect, $P>0.20)$. However, when the data were analyzed by ANOVA with repeated measures for each incubation measurement time point, the interaction of TZD by incubation time relative to PMA activation was significant (Figure 6A; $P<0.01$ ). Furthermore, the intracellular ROS production of neutrophils isolated from postpartum cows was 42.9 and $36.7 \%$ less compared with that of neutrophils isolated from midlactation and
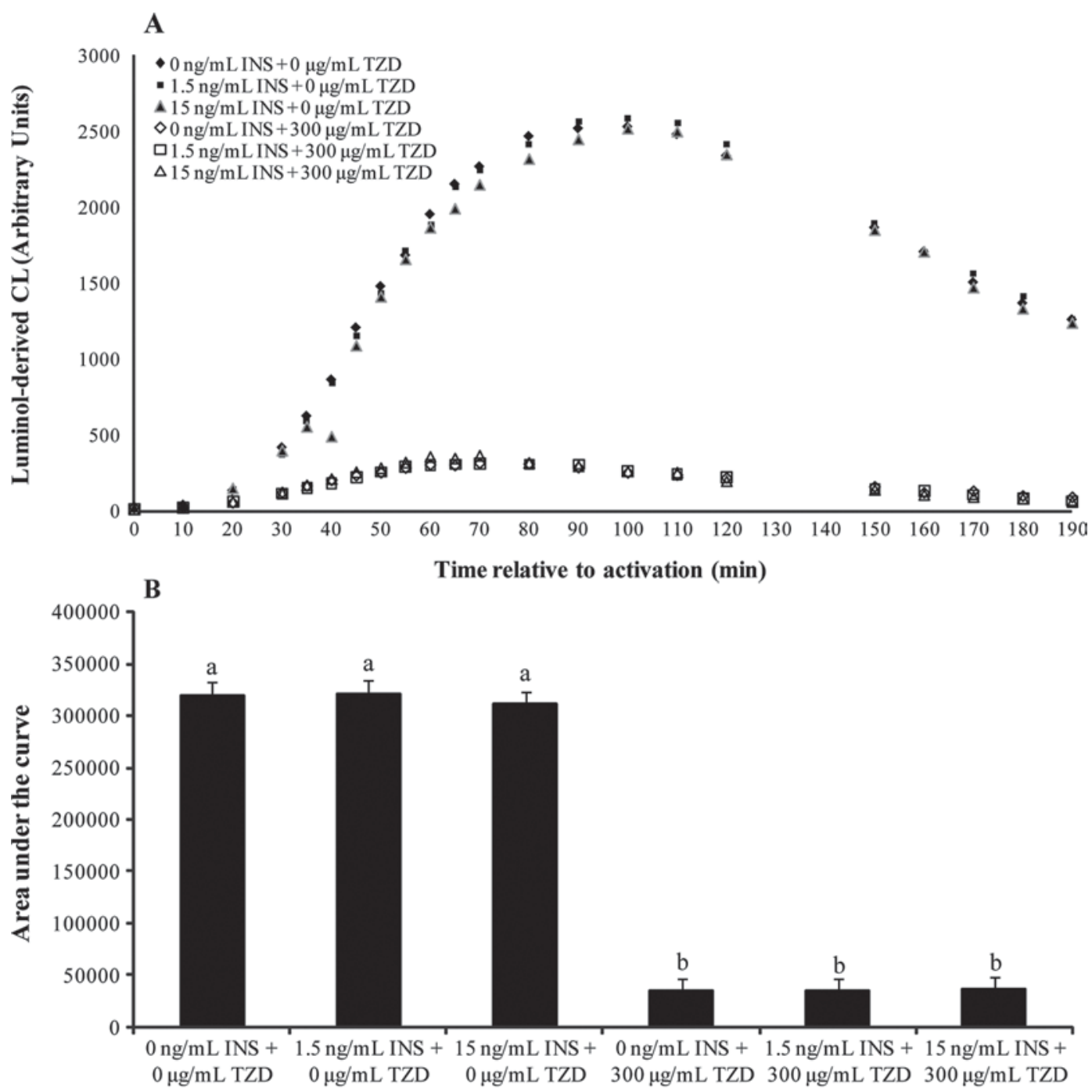

Treatment

Figure 1. Effect of insulin (INS) and 2,4-thiazolidinedione (TZD) on a proxy for the total reactive oxygen species production by bovine neutrophils. Neutrophils were collected from cows $(\mathrm{n}=25)$ and incubated for $120 \mathrm{~min}$ with $0,1.5$, or $15 \mathrm{ng} / \mathrm{mL}$ of insulin and $0 \mathrm{or} 300 \mu \mathrm{g} / \mathrm{mL}$ of TZD either alone or in combination with the insulin treatments. (A) Data represent the mean luminol-derived chemiluminescence (CL) in arbitrary units measured every 5 or 10 min over a 190-min period after activation of neutrophils with phorbol 12-myristate,13-acetate. The CL values of nonactivated neutrophils were subtracted from all the CL measurements at every time point. (B) To assess the overall magnitude of the luminol-dependent CL response over time, the area under the curve $( \pm \mathrm{SEM})$ was calculated from plotted luminol-derived measurements. Area under the curve differed by TZD treatment, $P<0.01$. ${ }^{\mathrm{a}, \mathrm{b}}$ Bars with different letters differ $(P<0.01)$. 


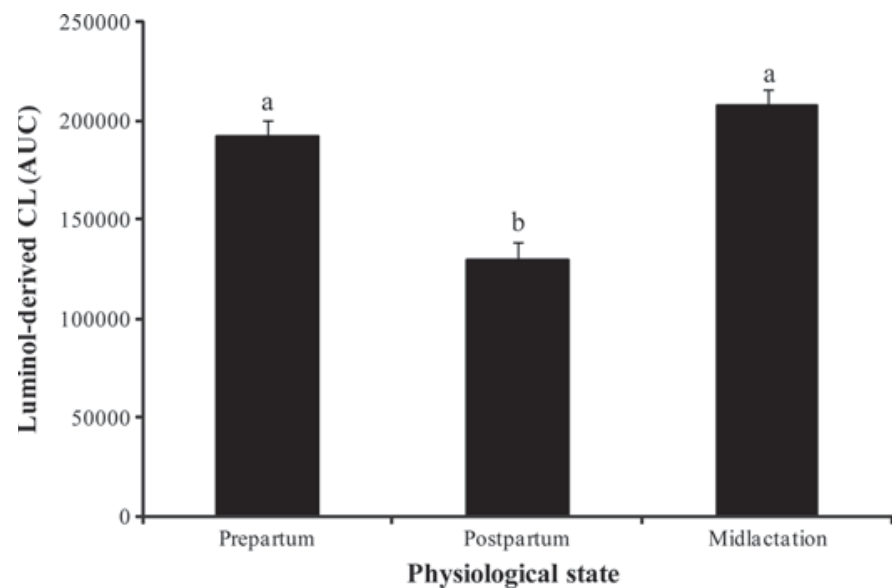

Figure 2. Effect of physiological state on a proxy for the total reactive oxygen species production by bovine neutrophils. Neutrophils were collected from pregnant midlactation $(253 \pm 25.2 \mathrm{~d}$ postpartum $\mathrm{n}=9)$, prepartum $(-12 \pm 1.7 \mathrm{~d} ; \mathrm{n}=8)$, and postpartum $(+7 \pm 0 \mathrm{~d}$; $\mathrm{n}=8$ ) cows. Data represent the area under the curve (AUC; \pm SEM) calculated from plotted luminol-derived measurements over a 190-min period after activation of neutrophils with phorbol 12-myristate,13-acetate. The chemiluminescence (CL) values of nonactivated neutrophils were subtracted from all the CL measurements at every time point Luminol-derived CL differed by physiological state, $P<0.01$. ${ }^{\mathrm{a}, \mathrm{b}}$ Bars with different letters differ $(P<0.01)$.

prepartum animals, respectively (Figure 7; physiological state effect, $P<0.01)$. However, the fluorescence values of PMNL collected from midlactation cows were similar to those of PMNL isolated from prepartum cows
(Figure $7 ; P>0.20$ ). There were no insulin-by-TZD or in vitro treatment-by-physiological state interaction effects on the PMNL intracellular generation of ROS as measured by $\mathrm{CM}-\mathrm{H}_{2} \mathrm{DCFDA}$-derived fluorescence (all interactions, $P>0.20$ ).

\section{NET Release}

There was no effect of insulin or TZD on NET release relative to control wells (Figure 8; effect of insulin or TZD, $P>0.20)$. However, the mean fluorescence associated with NET released from neutrophils collected from prepartum cows was 23 and $36 \%$ greater than that of PMNL collected from midlactation and postpartum cows, respectively (Figure 9; physiological state effect, $P<0.01)$. Neutrophil NET expression from midlactation cows was similar to that of PMNL isolated from postpartum cows (Figure 9; $P>0.20$ ). There were no insulin-by-TZD or in vitro treatment-by-physiological state interaction effects on PMNL NET release $(P>$ $0.20)$.

\section{Killing and Phagocytosis}

There was no effect of insulin or TZD or their combination on the percentage of cells positive for intracellular bacteria or the number of phagocytosed Staph. aureus per PMNL (Table 2; insulin or TZD effect, $P>$ $0.20)$. Neutrophils collected from postpartum cows had

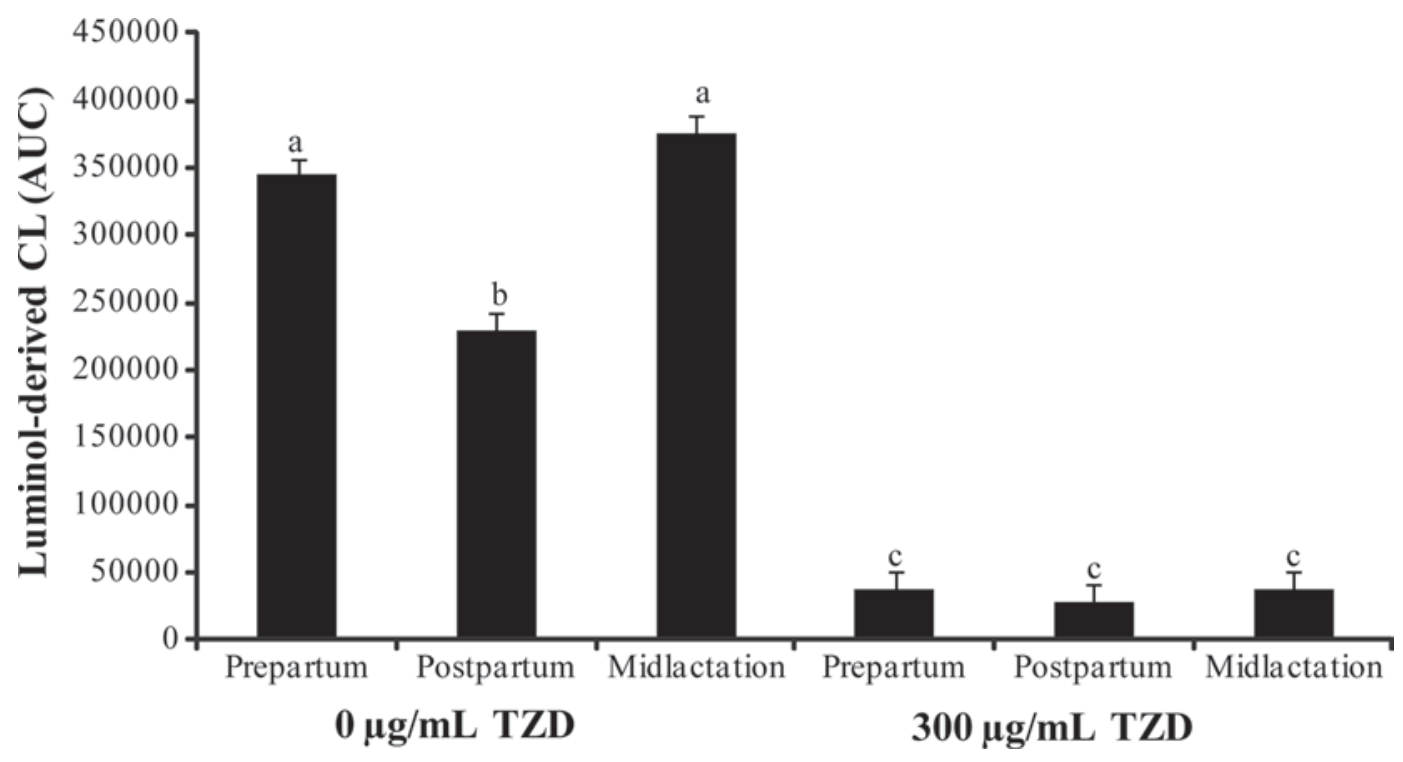

Figure 3. Effects of 2,4-thiazolidinedione (TZD) and physiological state on a proxy for the total reactive oxygen species production by bovine neutrophils. Neutrophils were collected from pregnant midlactation $(253 \pm 25.2 \mathrm{~d}$ postpartum; $\mathrm{n}=9)$, prepartum $(-12 \pm 1.7 \mathrm{~d} ; \mathrm{n}=$ $8)$, and postpartum $(+7 \pm 0 \mathrm{~d} ; \mathrm{n}=8)$ cows. Data represent the area under the curve (AUC; $\pm \mathrm{SEM})$ calculated from plotted luminol-derived measurements over a 190-min period after activation of neutrophils with phorbol 12-myristate,13-acetate. The chemiluminescence (CL) values of nonactivated neutrophils were subtracted from all the CL measurements at every time point. Luminol-derived CL differed by TZD $\times$ physiological state, $P<0.01 .{ }^{\text {a-c }}$ Bars with different letters differ $(P<0.01)$. 

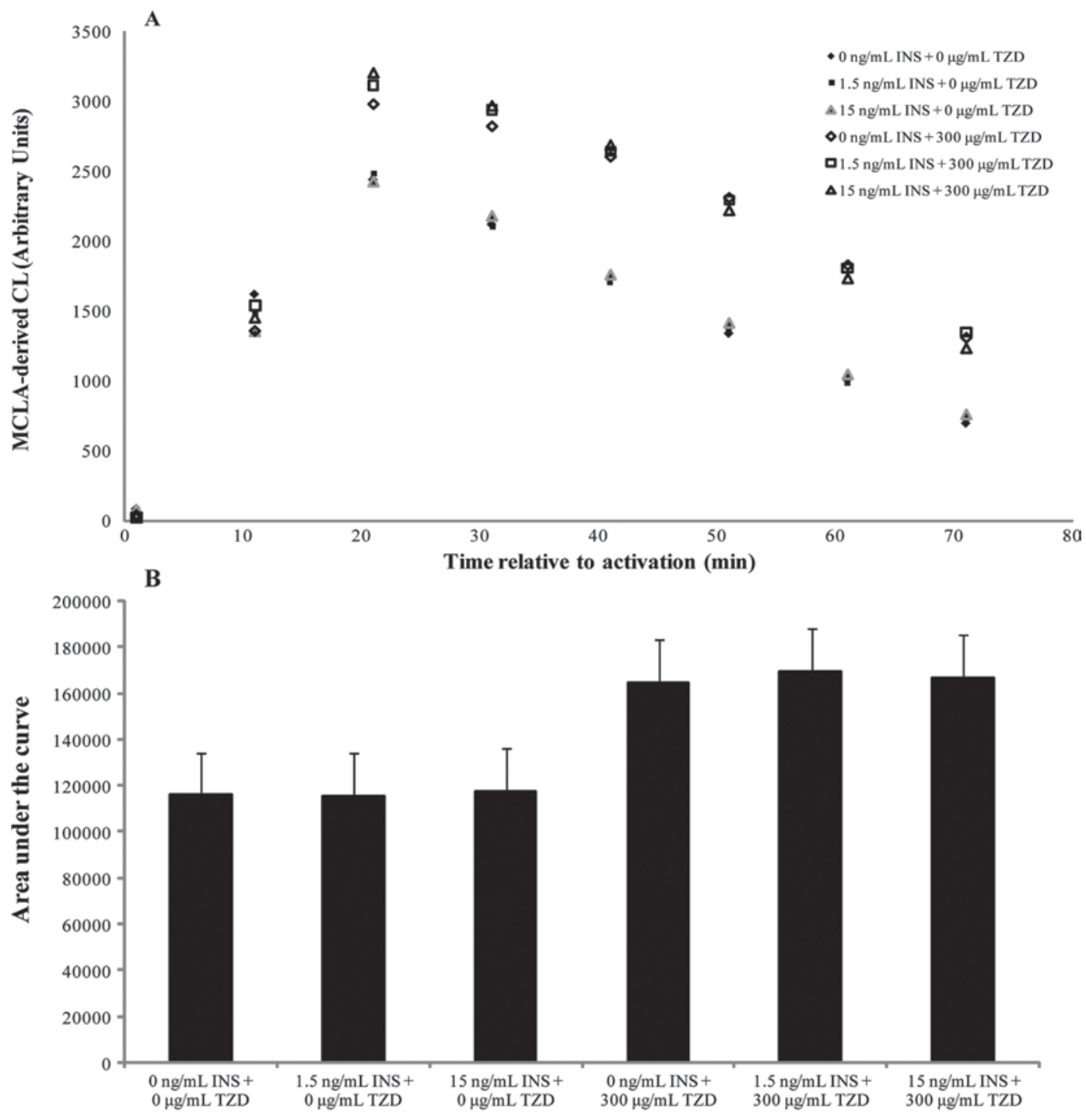

Treatment

Figure 4. Effect of insulin (INS) and 2,4-thiazolidinedione (TZD) on extracellular $\mathrm{O}_{2}{ }^{-}$production by bovine neutrophils. Neutrophils were collected from cows $(\mathrm{n}=26)$ and incubated for $120 \mathrm{~min}$ with $0,1.5$, or $15 \mathrm{ng} / \mathrm{mL}$ of insulin and 0 or $300 \mu \mathrm{g} / \mathrm{mL}$ of TZD either alone or in combination with the insulin treatments. (A) Mean methyl cypridina luciferin analog (MCLA)-dependent chemiluminescence (CL; arbitrary units) measured every $10 \mathrm{~min}$ over an 80-min period after activation of neutrophils with phorbol 12-myristate,13-acetate. The CL values of nonactivated neutrophils were subtracted from all the CL measurements at every time point. (B) To assess the overall magnitude of the luminoldependent CL response over time, the area under the curve $( \pm$ SEM) was calculated from plotted luminol-derived measurements. Area under the curve differed by TZD treatment, $P<0.01$.

a greater percentage of cells with phagocytosed bacteria and number of bacteria per neutrophil compared with those from prepartum and midlactation animals (Table 3 ; physiological state effect, $P<0.01$ ). There was no effect of insulin or TZD on the killing ability of PMNL (Table 2; insulin or TZD effect, $P>0.20$ ). However, the killing ability of neutrophils isolated from postpartum animals was 61 and $97 \%$ greater compared with that of neutrophils isolated from prepartum and midlactation animals, respectively (Table 3; physiological state effect, $P<0.01$ ). No in vitro treatment or physiological state interaction effects were evident (all interactions, $P>0.20)$.

\section{DISCUSSION}

A 2-h incubation of PMNL with a high physiological $(1.5 \mathrm{ng} / \mathrm{mL})$ or a supraphysiological $(15 \mathrm{ng} / \mathrm{mL})$ concentration of insulin had no effect on the respiratory burst activity, NET release, phagocytosis and killing ability of neutrophils isolated from cows in different physiological states. In contrast, in vitro experiments involving hu- 
man neutrophils indicate that insulin at physiological concentrations can influence some aspects of their function. For instance, a 30-min incubation with 5.8 and 58 $\mathrm{ng} / \mathrm{mL}$ of insulin stimulated the generation of hydrogen peroxide in a dose-responsive manner (Spagnoli et al., 1995), $1.4 \mathrm{ng} / \mathrm{mL}$ of insulin enhanced PMNL chemotaxis toward formyl-methionyl-leucyl-phenylalanine by approximately $50 \%$ (Cavalot et al., 1992), and $3.7 \mathrm{ng} /$ $\mathrm{mL}$ of insulin increased the expression of the neutrophil intercellular adhesion molecule-1 by approximately $80 \%$ after $48 \mathrm{~h}$ of incubation with the hormone (Okouchi et al., 2002). Also, it has been reported that patients with diabetes mellitus have increased susceptibility to and severity of infections (Bertoni et al., 2001) in part as a result of alterations in neutrophil phagocytosis, respiratory burst activity, and $\mathrm{H}_{2} \mathrm{O}_{2}$ production (AlbaLoureiro et al., 2006; Bilgic et al., 2008). A standard insulin 2-wk treatment improved neutrophil phagocytic capacity of diabetic patients with foot infections (Top et al., 2007) and after cardiac surgery (Rassias et al., 1999). However, studies investigating the effect of experimental hyperinsulinemia on neutrophil function in nondiabetic subjects have yielded conflicting results. For instance, Walrand et al. (2004) reported an increase in chemotaxis, phagocytosis, and bactericidal activities in PMNL collected from healthy individuals after a 4-h hyperinsulinemic euglycemic clamp, whereas Fejfarová et al. (2006) and Stegenga et al. (2008) did not find any alterations of phagocytosis, migration, and ROS production during induced hyperinsulinemia with strict euglycemia when compared with subjects receiving saline infusion. In summary, there is evidence from in vitro and in vivo studies in humans that insulin modulates neutrophil functionality, at least in individuals with defective insulinemia. In dairy cows, plasma insulin levels and the peripheral tissue sensitivity and responsiveness to insulin are reduced in the periparturient period compared with midlactation, as part of the homeorhetic adaptations that support the increased flux of nutrients toward pregnancy and lactation (Bell and Bauman, 1997). Thus, we hypothesized that in vitro incubation with greater insulin levels, alone or in combination with the PPAR- $\gamma$ agonist and insulin-sensitizing agent TZD, would have a differential effect on the functionality of periparturient PMNL relative to PMNL isolated from midlactation cows. The lack of a direct effect of insulin on bovine neutrophil activity may be an artifact of the experimental methods such as short incubation time or exposure to insulin at an insensitive time point of the PMNL life cycle. Alternatively, the lack of insulin effect may be explained by the relatively low levels of insulin receptors detected on bovine neutrophils (Nielsen et al., 2003). Perhaps, in dairy cows, insulin does not regulate neutrophil function directly but might act indirectly

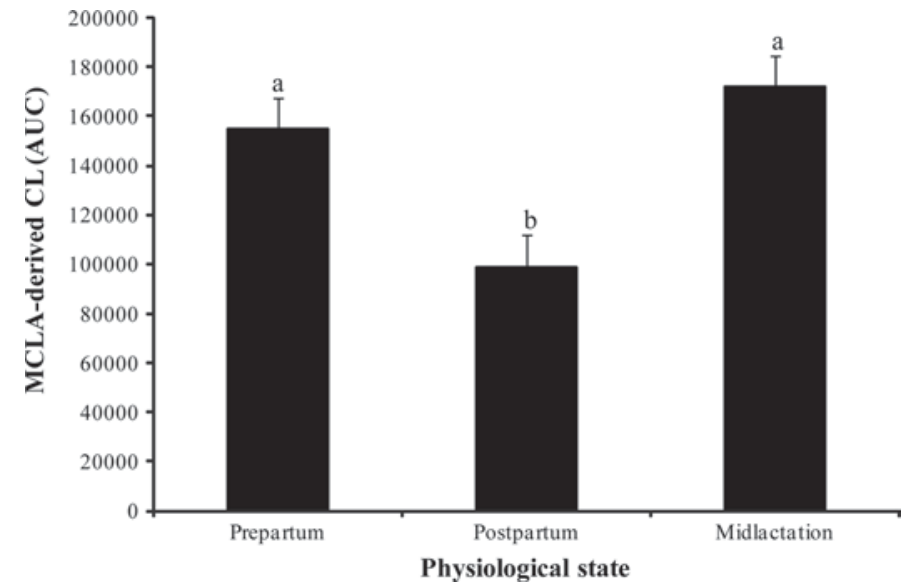

Figure 5. Effect of physiological state on extracellular $\mathrm{O}_{2}^{-}$production by bovine neutrophils. Neutrophils were collected from pregnant midlactation $(253 \pm 25.2 \mathrm{~d}$ postpartum; $\mathrm{n}=9)$, prepartum $(-12 \pm$ $1.7 \mathrm{~d} ; \mathrm{n}=8)$, and postpartum $(+7 \pm 0 \mathrm{~d} ; \mathrm{n}=9)$ cows. Data represent the area under the curve (AUC; \pm SEM) calculated from plotted methyl cypridina luciferin analog (MCLA)-derived measurements over a 70-min period after activation of neutrophils with phorbol 12 -myristate,13-acetate. The chemiluminescence (CL) values of nonactivated neutrophils were subtracted from all the CL measurements at every time point. MCLA-derived CL differed by physiological state, $P<0.01 .{ }^{\mathrm{a}, \mathrm{b}}$ Bars with different letters differ $(P<0.01)$.

via improvement of metabolic control during the periparturient period. For instance, insulin may reduce the level of circulating NEFA and ketone bodies that have detrimental effects on neutrophil and leukocyte activity (Suriyasathaporn et al., 1999; Scalia et al., 2006). Thus, the in vivo effect of insulin on periparturient neutrophil function requires investigation.

Incubation of PMNL with TZD resulted in a potent inhibitory effect on the neutrophil luminol-dependent $\mathrm{CL}$, an indicator of the PMNL generation of a wide array of ROS including extracellular and intracellular hydroxyl radical $\left(\mathrm{OH}^{-}\right)$, peroxynitrite $\left(\mathrm{ONOO}^{-}\right)$, hypochlorous acid $(\mathrm{HClO})$, intracellular superoxide $\left(\mathrm{O}_{2}{ }^{-}\right)$, and hydrogen peroxide $\left(\mathrm{H}_{2} \mathrm{O}_{2}\right)$ (Rinaldi et al., 2007). Furthermore, TZD had no effect on the generation of intracellular $\mathrm{NO}, \mathrm{ONOO}^{-}$, and $\mathrm{H}_{2} \mathrm{O}_{2}$ assessed by the $\mathrm{CM}-\mathrm{H}_{2} \mathrm{DCFDA}$ fluorescence assay, when the differences were assessed by calculated AUC. However, when the data were analyzed by ANOVA with repeated measures, treatment of PMNL with TZD resulted in a modest decrease in the generation of $\mathrm{CM}_{-} \mathrm{H}_{2} \mathrm{DCFDA}$-derived intracellular ROS 140 min after cell activation. Perhaps TZD has a delayed inhibitory effect on the generation of these intracellular ROS relative to luminol-derived ROS, but the duration of our assay might not have allowed us to observe the decrease in these intracellular ROS to its full extent. Overall, the decreased respiratory burst activity is consistent with the emerging evidence regarding the anti-inflammatory effects of thiazolidin- 


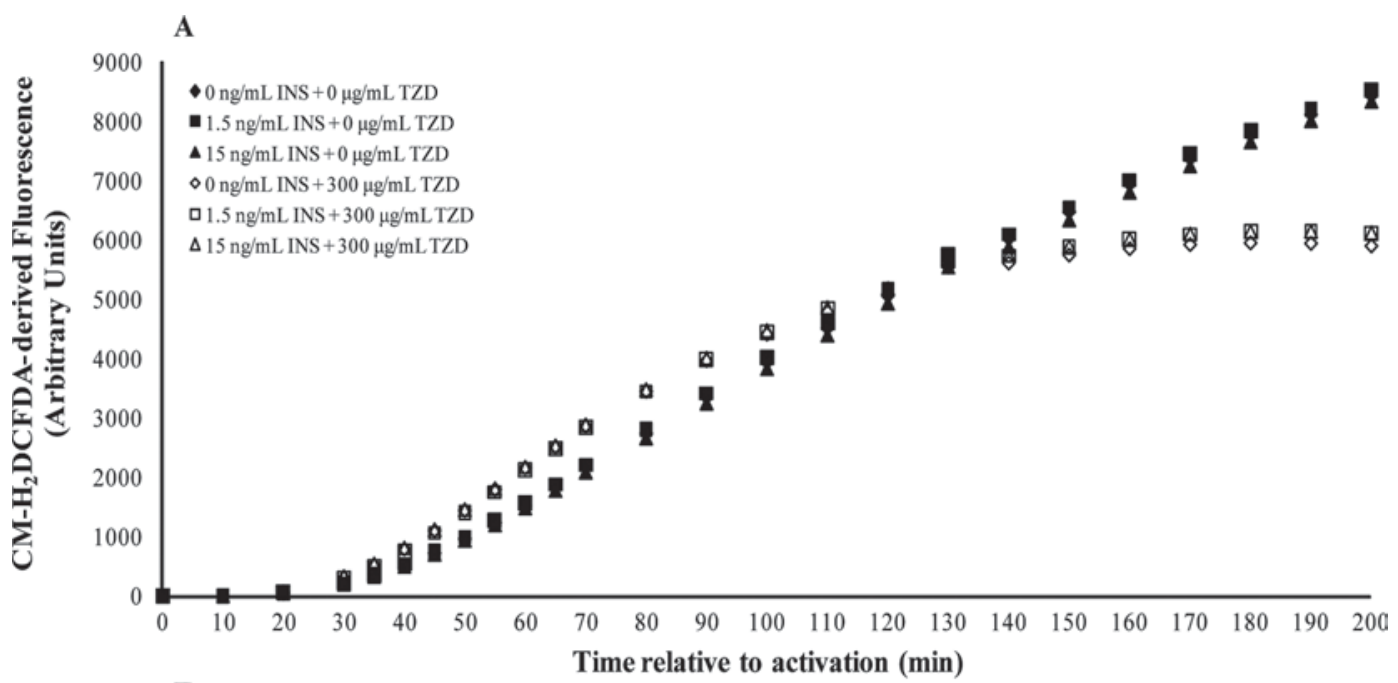

B

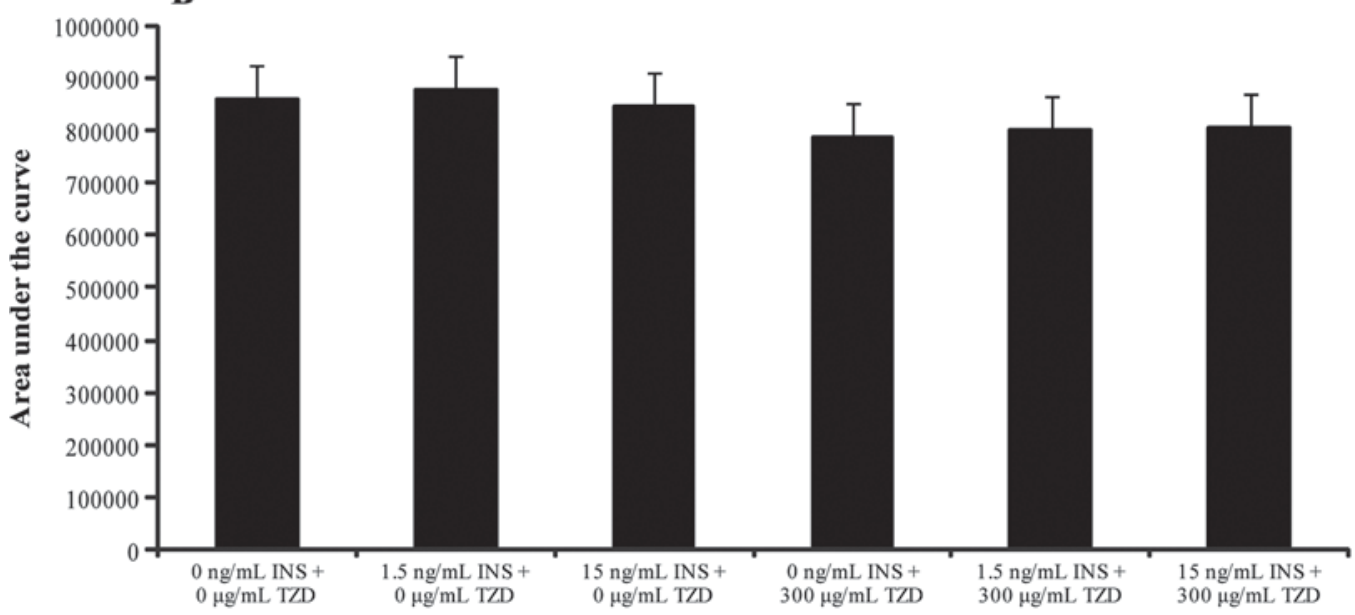

Treatment

Figure 6. Effect of insulin (INS) and 2,4-thiazolidinedione (TZD) on a proxy for the intracellular reactive oxygen species production by bovine neutrophils. Neutrophils were collected from cows $(\mathrm{n}=24)$ and incubated for 120 min with $0,1.5$, or $15 \mathrm{ng} / \mathrm{mL}$ of insulin and 0 or 300 $\mu \mathrm{g} / \mathrm{mL}$ of TZD. Data represent the mean 5-(6)-chloromethyl-2',7'-dichlorodihydrofluorescein di-acetate acetyl ester $\left(\mathrm{CM}-\mathrm{H}_{2} \mathrm{DCFDA}\right)$-derived fluorescence in arbitrary units measured every $10 \mathrm{~min}$ over a 200 -min period after activation of neutrophils with phorbol 12 -myristate,13-acetate (PMA). The fluorescence values of nonactivated neutrophils were subtracted from all measurements at every time point. Incubation with TZD affected neutrophil $\mathrm{CM}-\mathrm{H}_{2} \mathrm{DCFDA}$-derived fluorescence over time (panel A; treatment by time effect, $P<0.01$ ), but did not affect the overall magnitude of $\mathrm{CM}-\mathrm{H}_{2} \mathrm{DCFDA}$-derived fluorescence from neutrophils as measured by area under the curve analysis (panel B, insulin or TZD effect, $P>0.20)$.

ediones and other PPAR- $\gamma$ ligands. Importantly, these effects are thought to be mediated by the inhibition of the nuclear factor $\kappa \mathrm{B}$, which during inflammation, enters the nucleus and activates the expression of several proinflammatory genes, including cytokines and enzymes necessary for the production of ROS (Karin and Ben-Neriah, 2000; Rutledge and Adeli, 2007). Indeed, Ghanim et al. (2001) treated obese subjects with troglitazone, an insulin sensitizer and PPAR- $\gamma$ ligand of the TZD class, and reported a marked fall in ROS generation by mononuclear cells together with a decrease in the expression of NADPH oxidase, nuclear facter $\kappa \mathrm{B}$, and I $\kappa$ B proteins. These TZD anti-inflammatory effects might be independent of metabolic alterations because administration of a lesser dose of a TZD to diabetic patients resulted in decreased inflammatory markers without changes in glucose homeostasis, plasma insulin, and FFA (Ghanim et al., 2006). Reactive oxygen species produced during neutrophil phagocytosis are essential to trigger apoptosis of neutrophils (Zhang et al., 2003). Thus, imbalances in PMNL intracellular ROS generation may reduce their viability. Importantly, the reduction of ROS generation by TZD observed in this study was not accompanied by an impaired ability of the neutrophils to release NET or engulf and kill bacteria, suggesting that TZD may reduce inflammation 


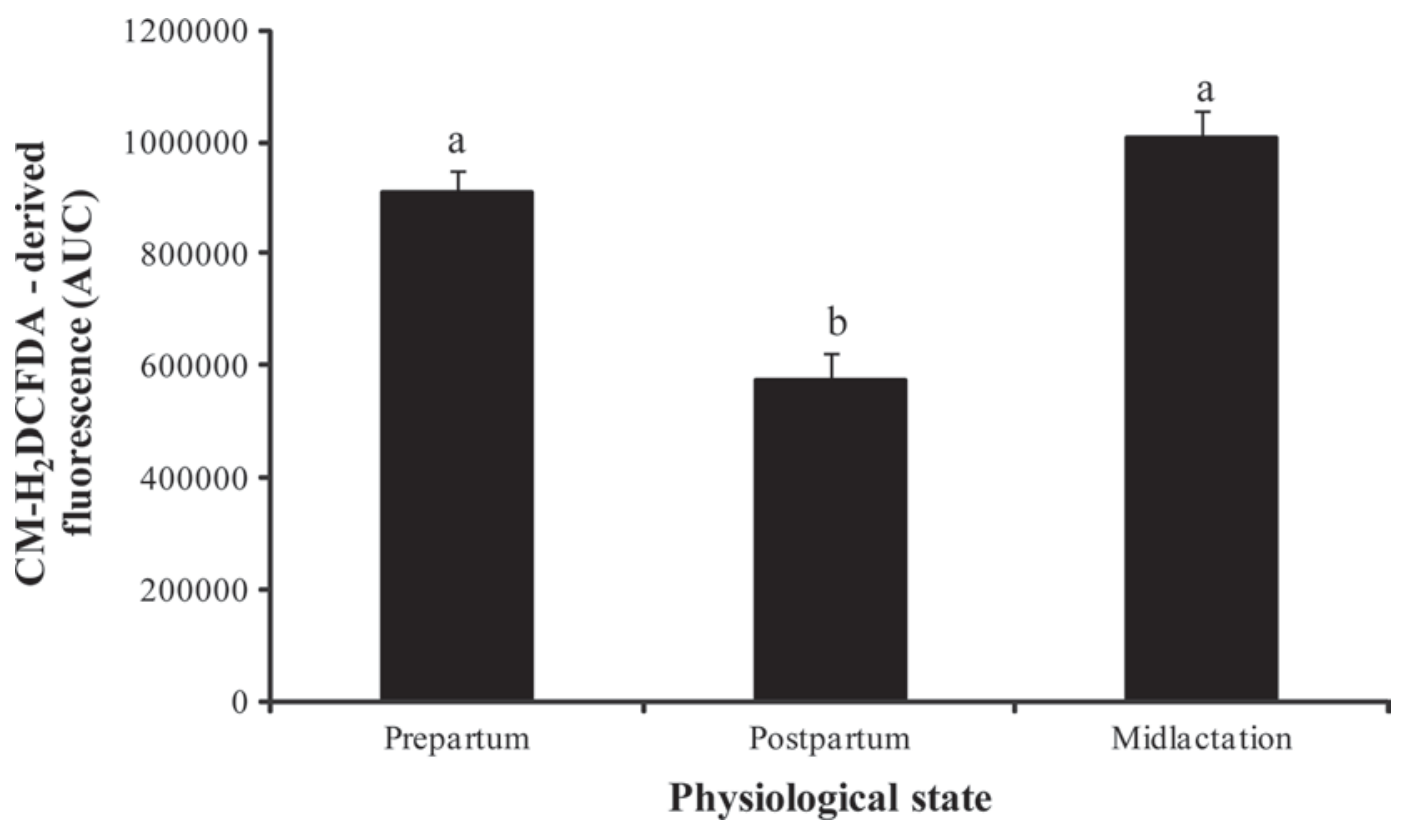

Figure 7. Effect of physiological state on a proxy for the intracellular reactive oxygen species production by bovine neutrophil. Neutrophils were collected from pregnant midlactation $(253 \pm 25.2 \mathrm{~d}$ postpartum; $\mathrm{n}=9)$, prepartum $(-12 \pm 1.7 \mathrm{~d} ; \mathrm{n}=8)$, and postpartum $(+7 \pm 0 \mathrm{~d} ; \mathrm{n}=$ 7 ) cows. Data represent the area under the curve (AUC; \pm SEM) calculated from plotted 5-(6)-chloromethyl-2', $7^{\prime}$-dichlorodihydrofluorescein diacetate acetyl ester $\left(\mathrm{CM}-\mathrm{H}_{2}\right.$ DCFDA)-derived measurements over a 200-min period after activation of neutrophils with phorbol 12-myristate,13acetate. The chemiluminescence (CL) values of nonactivated neutrophils were subtracted from all the CL measurements at every time point. CM- $\mathrm{H}_{2}$ DCFDA-derived fluorescence differed by physiological state, $P<0.01$. ${ }^{\mathrm{a}, \mathrm{b}}$ Bars with different letters $\operatorname{differ}(P<0.01)$.

while leaving the essential antimicrobial capacity of neutrophils intact.

Excess ROS production can damage the host cell membrane by peroxidation of the components of the lipid bilayer (Fialkow et al., 2007) or ultimately promote injury to the surrounding tissue (Capuco et al.,
1986). It is conceivable that TZD has different effects on individual ROS produced by bovine PMNL. Neutrophils incubated with TZD had increased concentrations of extracellular $\mathrm{O}_{2}{ }^{-}$measured by MCLA-derived CL, yet displayed lesser generation of $\mathrm{H}_{2} \mathrm{O}_{2}, \mathrm{OH}^{-}, \mathrm{ONOO}^{-}$, and $\mathrm{HClO}$. The reason for these inconsistent results

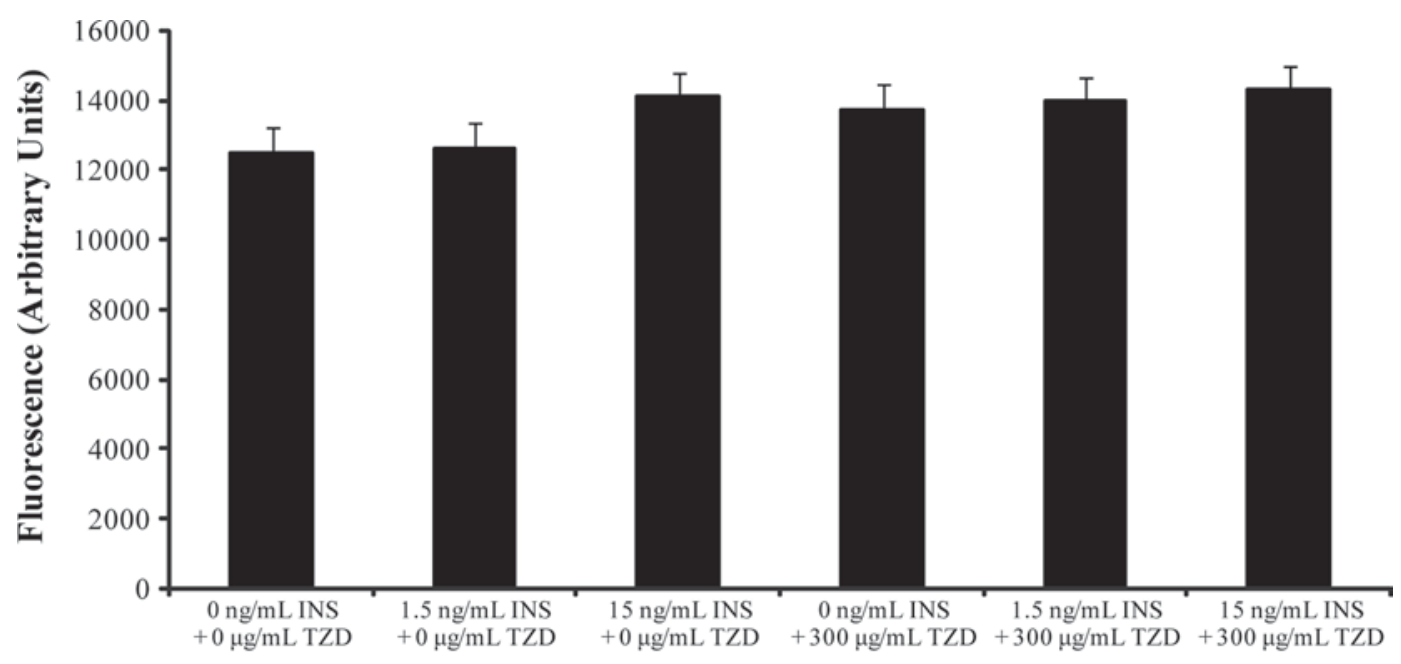

Treatment

Figure 8. Effect of insulin (INS) and 2,4-thiazolidinedione (TZD) on neutrophil extracellular traps expression. Neutrophils were collected from cows $(\mathrm{n}=24)$ and incubated for $120 \mathrm{~min}$ with $0,1.5$, or $15 \mathrm{ng} / \mathrm{mL}$ of insulin and 0 or $300 \mu \mathrm{g} / \mathrm{mL}$ of TZD. Data represent the mean fluorescence in arbitrary units measured after a 1-h incubation of neutrophils with phorbol 12-myristate,13-acetate. The fluorescence values of nonactivated neutrophils were subtracted from all measurements. 


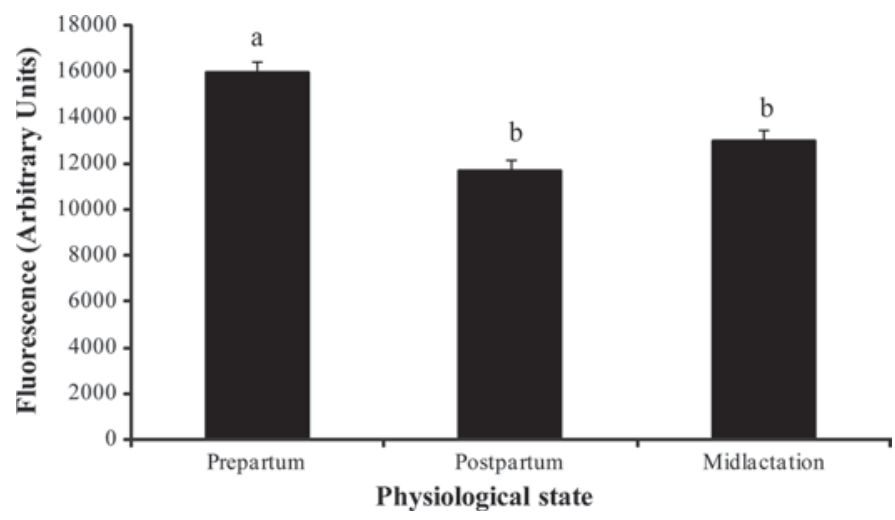

Figure 9. Effect of physiological state on neutrophil extracellular traps expression. Neutrophils were collected from pregnant midlactation $(253 \pm 25.2$ d postpartum; $\mathrm{n}=8)$, prepartum $(-12 \pm 1.7 \mathrm{~d} ; \mathrm{n}$ $=8)$, and postpartum $(+7 \pm 0 \mathrm{~d} ; \mathrm{n}=8)$ cows. Data represent mean fluorescence $( \pm$ SEM) of cells stained with Sytox Orange (Invitrogen Co., Eugene, OR) after a 1-h incubation with phorbol 12-myristate,13acetate. The fluorescence values of nonactivated neutrophils were subtracted from all measurements. Fluorescence differed by physiological state, $P<0.01$. ${ }^{\mathrm{a}, \mathrm{b}}$ Bars with different letters differ $(P<0.01)$.

is not obvious, but differential regulation of mitochondrial, cytosolic, and extracellular superoxide dismutase isozymes has been reported by others (Marklund, 1992; Miao and St. Clair, 2009). Furthermore, results from our luminol assay indicated that TZD inhibited the production of $\mathrm{O}_{2}^{-}, \mathrm{H}_{2} \mathrm{O}_{2}, \mathrm{OH}^{-}$, $\mathrm{ONOO}^{-}$, and $\mathrm{HClO}$ by $89 \%$. Although the specific identity or cellular location of the remaining $11 \%$ ROS is uncertain, extracellular $\mathrm{O}_{2}{ }^{-}$contributed to $41 \%$ of the ROS detected by luminoldependent CL (Rinaldi et al., 2007). Even if we assume that TZD augments both intra- and extracellular $\mathrm{O}_{2}{ }^{-}$, this increase does not represent more than $4.5 \%$ of the total ROS because $\mathrm{O}_{2}^{-}$should account for $41 \%$ of the $11 \%$ ROS that was noninhibited by TZD. In addition, $\mathrm{O}_{2}^{-}$is relatively nonreactive with most biological substrates and has less oxidative potential compared with other ROS. In fact, $\mathrm{O}_{2}{ }^{-}$is between 100 and 1,000 times less toxic than other powerful oxidants produced by the PMNL such as HOCl (Conner and Grisham, 1996). Therefore, the increase in extracellular $\mathrm{O}_{2}{ }^{-}$in response to TZD observed in our MCLA assay is less striking relative to the large decrease in total ROS determined by luminol-derived CL.

In vivo administration of TZD to periparturient cows might enhance immune function directly by acting on PMNL as discussed above. These effects can be exerted on neutrophils as reported in our study or on other leukocytes, as suggested by experiments involving human peripheral mononuclear cells (Jiang et al., 1998) and macrophages (Ricote et al., 1998). It is possible that TZD can improve the immunity of periparturient cows indirectly by improving glucose metabolism of leukocytes. For instance, in vivo administration of TZD restored the insulin-mediated glucose utilization of steers with insulin resistance induced by recombinant bovine tumor necrosis factor- $\alpha$ (Kushibiki et al., 2001). Although glucose uptake by PMNL is not insulin dependent (Maratou et al., 2007), TZD could enhance glucose metabolism by acting on intracellular events that regulate its utilization. In rats, administration of $15 \mathrm{mg} / \mathrm{kg}$ per d of rosiglitazone, a PPAR- $\gamma$ agonist of the TZD family, enhanced inguinal fat glucose oxidation and its incorporation into glycogen by $112 \%$ and $85 \%$, respectively, an effect accompanied by increased mRNA levels of phosphofructokinase, pyruvate dehydrogenase, lactate dehydrogenase, cytochrome oxidase, citrate synthase, and isocitrate dehydrogenase (Festuccia et al., 2009). Interestingly, TZD also seems to enhance glucose utilization in tissues in which glucose uptake is not dependent on insulin. For example, in vitro incubation of brain glial cells from rats with pioglitazone, also a member of the TZD subclass of antidiabetic drugs, increased glucose consumption and lactate production via the cAMP-protein kinase A pathway in a time- and dose-dependent manner (Dello Russo et al., 2003). In dairy cows, infusion of TZD during the last $25 \mathrm{~d}$ of pregnancy resulted in a $15 \%$ reduction of prepartum plasma NEFA concentration and a decrease of plasma BHBA concentration as parturition approached compared with control animals (Smith et al., 2007). Thus, TZD might contribute to mammary gland health by reducing the plasma concentration of NEFA and BHBA that have been shown to have negative effects on PMNL function (Hoeben et al., 1997; Scalia et al., 2006).

Table 2. Effect of insulin (INS) and 2,4-thiazolidinedione (TZD) on the bactericidal and phagocytic abilities of neutrophils against Staphylococcus aureus $^{1}$

Treatment $(\mathrm{ng} / \mathrm{mL}$ of INS $+\mu \mathrm{g} / \mathrm{mL}$ of TZD)

\begin{tabular}{lccccc}
\cline { 2 - 6 } Index & $0+0$ & $1.5+0$ & $15+0$ & $0+300$ & $1.5+300$ \\
\hline PMNL with phagocytosed bacteria (\%) & $27.3 \pm 4$ & $26.0 \pm 4$ & $25.5 \pm 4$ & $23.7 \pm 4$ & $24.1 \pm 4$ \\
Number of engulfed bacteria per PMNL & $13.0 \pm 1$ & $13.4 \pm 1$ & $12.3 \pm 1$ & $12.6 \pm 1$ & $12.9 \pm 1$ \\
Killing ability (\%) & $23.3 \pm 4$ & $24.8 \pm 4$ & $23.7 \pm 4$ & $22.7 \pm 4$ & $21.7 \pm 4$ \\
\hline
\end{tabular}

${ }^{1}$ Data are means $\pm \operatorname{SEM}(\mathrm{n}=24)$. 
Table 3. Effect of physiological state on the bactericidal and phagocytic abilities of neutrophils against Staphylococcus aureus

\begin{tabular}{lllc}
\hline Index & Prepartum & Postpartum & Midlactation \\
\hline PMNL with phagocytosed bacteria (\%) & $21.7 \pm 2.8^{\mathrm{a}}$ & $40.2 \pm 2.8^{\mathrm{b}}$ & $13.1 \pm 2.8^{\mathrm{a}}$ \\
Number of engulfed bacteria per PMNL & $11.4 \pm 0.6^{\mathrm{a}}$ & $15.4 \pm 0.6^{\mathrm{b}}$ & $11.5 \pm 0.6^{\mathrm{a}}$ \\
Killing ability (\%) & $19.9 \pm 2.7^{\mathrm{a}}$ & $32.1 \pm 2.7^{\mathrm{b}}$ & $16.3 \pm 2.6^{\mathrm{a}}$ \\
\hline
\end{tabular}

${ }^{a, b}$ Values in the same row with different superscripts differ $(P<0.01)$.

${ }^{1}$ Data are means \pm SEM $(\mathrm{n}=8)$. Effect of physiological state, $P<0.01$.

As with any in vitro system, it is impossible to completely duplicate the in vivo physiologic environment, and it is possible that in vitro conditions may have affected basal cellular metabolism or PMNL ability to respond to treatment. For example, the calcium-free environment of the HBSS incubation media increases the precision of the CL assays; however, it is possible that the low calcium environment could influence cellular metabolism. Doré et al. (1990) reported that the level of cytosolic $\mathrm{Ca}^{2+}$, intracellular $\mathrm{Ca}^{2+}$ flux, and apparent activation of bovine PMNL incubated in $\mathrm{Ca}^{2+}$ free buffer media was less than when cells were incubated in the presence of extracellular $\mathrm{Ca}^{2+}$. Experimentally induced hypocalcemia in periparturient cows had no effect on in vitro ROS generation, ingestion of Staph. aureus, and antibody-dependent cell-mediated cytotoxicity by PMNL, at least when these assays were performed in medium buffer containing physiological levels of $\mathrm{Ca}^{2+}$ (Kehrli and Goff, 1989). In contrast, Kimura et al. (2006) reported that the flux of intracellular ionized calcium in peripheral mononuclear cells stimulated with an anti-CD3-secondary antibody complex was reduced in periparturient cows diagnosed with milk fever compared with healthy animals. It is unknown whether the low $\mathrm{Ca}^{2+}$ concentration in our in vitro system may have attenuated PMNL activity similar to that reported by Doré et al. (1990); however, all assay activators utilized resulted in dramatic and sustained cellular responses, and several significant effects of treatment are reported, most of which are consistent with other peer-reviewed research.

The luminol-, CM- $\mathrm{H}_{2}$ DCFDA-, and MCLA-derived ROS production of blood neutrophils collected from prepartum and postpartum cows was reduced compared with that of PMNL isolated from midlactation animals. These results are in concordance with previous reports (Dosogne et al., 1999; Hoeben et al., 2000; Mehrzad et al., 2001, 2002) and can be partially explained by the decrease in the protein abundance (Lippolis et al., 2006a) and activity (Cai et al., 1994) of the enzyme myeloperoxidase reported in early lactation. However, no difference in ROS production was detected between prepartum and postpartum cows. There are conflicting reports regarding the changes in ROS generation between the prepartum and early lactation period. For instance, Hoeben et al. (2000) and Dosogne et al. (1999) reported a reduction in luminol-dependent CL beginning $\sim 3$ wk before parturition with minimum levels 1 wk after calving, but only the second group reported a significant decrease in PMA-induced CL of neutrophils between -1 and 1 wk after parturition. The results of the current study confirm that the respiratory burst activity of blood neutrophils from cows in early lactation, independently of the cellular location of ROS, is impaired and perhaps contributes to the period of high incidence and severity of infectious diseases that cows experience around the time of calving (Mallard et al., 1998; Vangroenweghe et al., 2005).

The PMNL from prepartum cows expressed greater levels of NET compared with mid-and early-lactation animals. Contrary to the oxygen-dependent killing mechanisms, NET may not experience a period of reduced functionality during the periparturient period. Lippolis et al. (2006b) reported that incubation of PMNL in milk, in contrast with other aspects of neutrophil function, did not reduce their ability to release NET, suggesting that when other PMNL killing mechanisms are impaired, neutrophils might rely on the antimicrobial activity of NET. Lippolis et al. (2006a) also performed a proteomic analysis of bovine PMNL collected during midlactation and $28 \mathrm{~d}$ before calving and reported that those from prepartum cows had greater levels of the histones H2B.e and H2B.f. Because these histones are structural components of NET (Brinkmann et al., 2004), their enhanced expression may contribute to the increased NET synthesis in prepartum versus midlactation cows observed in our study.

The phagocytic capacity assessed by the percentage of PMNL with engulfed Staph. aureus and the number of intracellular bacteria of neutrophils from early-lactation cows was increased compared with that of prepartum and midlactation animals. Increases in neutrophil phagocytic activity during the periparturient period have also been reported in several studies (Guidry et al., 1976; Kehrli et al., 1989; Detilleux et al., 1995; Dosogne et al., 1999). Detilleux et al. (1995) suggested that periparturient PMNL phagocytosis is increased because PMNL use the extra energy avail- 
able for phagocytic processes in a period when the consumption of energy for production of ROS is reduced. Conversely, Cai et al. (1994) and Daniel et al. (1991) reported no change in neutrophil phagocytosis during the periparturient period, whereas Dosogne et al. (2001) found no difference in phagocytosis between PMNL collected from midlactation, prepartum, and postpartum cows. This inconsistency in findings may be attributed to the different pathogens and neutrophil-to-pathogen ratios used in the in vitro cocultures. However, in contrast with other aspects of neutrophil function, none of these reports indicated that the phagocytic ability of neutrophils is impaired during the periparturient period, suggesting that decreased phagocytic ability may not contribute to periparturient immunosuppression.

In this study, the killing ability of PMNL from earlylactation cows against Staph. aureus was greater than that of prepartum and midlactation animals. Studies that have measured the bactericidal activity of blood neutrophils during the periparturient period have reported a decrease (Daniel et al., 1991; Detilleux et al., 1995; Dosogne et al., 2001) or no change (Kehrli et al., 1989; Cai et al., 1994) in the killing capacity of PMNL during early lactation compared with prepartum and midlactation. Daniel et al. (1991) and Detilleux et al. (1995) also observed a transient increase in the killing capacity of PMNL during the last 4 wk before calving followed by a decrease during the first week of lactation. Interestingly, the decrease in PMNL cell-mediated cytotoxicity during the first week of lactation reported by Cai et al. (1994) was observed only in cows with retained placenta, mastitis, or metritis, whereas the cytotoxicity of PMNL from clinically normal cows did not change from weeks -1.5 to 4 relative to parturition. Furthermore, PMNL purified from milk did not experience a reduction in the ability to kill Staph. aureus during the periparturient period (Daniel et al., 1991; Detilleux et al., 1995), and it is possible that the increase in immature PMNL in blood that occurs around parturition (Guidry et al., 1976) might be responsible for the differences in bactericidal capacities between blood and milk PMNL populations. Perhaps, changes in the population of mature and juvenile PMNL in blood might help explain the discrepancy of results regarding the antimicrobial capacity of PMNL during the periparturient period. Differences in methodologies used to determine bactericidal killing could also justify the inconsistency of the findings. Detilleux (2004) applied mathematical models that described the changes in bacteria number during exposure to PMNL in vitro and determined that the bacteria-to-neutrophil ratio should be within the range of 12:1 and 175:1 for effective phagocytosis and killing. The same author suggested that ratios outside these limits will result in defective killing of bacteria. Cognizant of these results, we initially attempted a bacteria-to-PMNL ratio ranging from 32:1 down to $12: 1$; however, validation of the assay in our laboratory was not possible until a bacteria-to-PMNL ratio of 4:1 was achieved. Therefore, the conflicting results of our study may be attributed to the lower 4:1 bacteria-to-PMNL ratio that we used in our coculture in an effort to reduce the number of intracellular bacteria and improve counting precision during light microscopy. Although admittedly counterintuitive, this ratio may also be responsible for the overall lesser killing percentages obtained in our assays (21\%) compared with the $57 \%$ reported by Rinaldi et al. (2006), who performed a killing assay under similar conditions, except for a greater 16:1 bacteria-to-neutrophil ratio. In addition, the lesser killing percentage obtained in our experiments may have resulted in an accumulation of phagocytosed bacteria within the cell that may have been responsible for our inability to accurately and precisely enumerate bacteria within PMNL when coincubated at greater ratios.

\section{CONCLUSIONS}

Our results suggest that insulin has no direct effect on bovine neutrophil function, but TZD increased the generation of extracellular superoxide anion and strongly inhibited the release of other intracellular and extracellular ROS. Interestingly, these anti-inflammatory effects of TZD did not interfere with the overall neutrophil phagocytosis and killing ability, suggesting that TZD may reduce the cell oxidative stress without diminishing antimicrobial activity. Furthermore, TZD did not reduce NET expression, a killing mechanism that may be particularly important to the health of the mammary gland. These direct effects of TZD on PMNL function coupled with potential indirect effects of TZD on immunity via circulating metabolites suggest a potential important role for TZD in improving periparturient immune function and health. As indicated by 3 assays to measure PMNL ROS production, the respiratory burst of PMNL is impaired in early lactation and may contribute to the state of immunosuppression. Interestingly, NET formation was not impaired postpartum and was actually increased in prepartum dairy cows.

\section{REFERENCES}

Alba-Loureiro, T. C., S. M. Hirabara, J. R. Mendonca, R. Curi, and T. C. Pithon-Curi. 2006. Diabetes causes marked changes in function and metabolism of rat neutrophils. J. Endocrinol. 188:295-303.

Bell, A. W., and D. E. Bauman. 1997. Adaptations of glucose metabolism during pregnancy and lactation. J. Mammary Gland Biol. Neoplasia 2:265-278. 
Bertoni, A. G., S. Saydah, and F. L. Brancati. 2001. Diabetes and the risk of infection-related mortality in the US. Diabetes Care 24:1044-1049.

Bilgic, S., E. Aktas, F. Salman, G. Ersahin, G. Erten, M. T. Yilmaz, and G. Deniz. 2008. Intracytoplasmic cytokine levels and neutrophil functions in early clinical stage of type 1 diabetes. Diabetes Res. Clin. Pract. 79:31-36.

Brinkmann, V., U. Reichard, C. Goosmann, B. Fauler, Y. Uhlemann, D. S. Weiss, Y. Weinrauch, and A. Zychlinsky. 2004. Neutrophil extracellular traps kill bacteria. Science 303:1532-1535.

Cai, T. Q., P. G. Weston, L. A. Lund, B. Brodie, D. J. McKenna, and W. C. Wagner. 1994. Association between neutrophil functions and periparturient disorders in cows. Am. J. Vet. Res. 55:934-943.

Capuco, A. V., M. J. Paape, and S. C. Nickerson. 1986. In vitro study of polymorphonuclear leukocyte damage to mammary tissues of lactating cows. Am. J. Vet. Res. 47:663-668.

Cavalot, F., G. Anfossi, I. Russo, E. Mularoni, P. Massucco, S. Burzacca, L. Mattiello, and M. Trovati. 1992. Insulin, at physiological concentrations, enhances the polymorphonuclear leukocyte chemotactic properties. Horm. Metab. Res. 24:225-228.

Conner, E. M., and M. B. Grisham. 1996. Inflammation, free radicals, and antioxidants. Nutrition 12:274-277.

Daniel, L. R., B. P. Chew, T. S. Tanaka, and L. W. Tjoelker. 1991. Beta-carotene and vitamin A effects on bovine phagocyte function in vitro during the peripartum period. J. Dairy Sci. 74:124-131.

Dello Russo, C., V. Gavrilyuk, G. Weinberg, A. Almeida, J. P. Bolanos, J. Palmer, D. Pelligrino, E. Galea, and D. L. Feinstein. 2003. Peroxisome proliferator-activated receptor gamma thiazolidinedione agonists increase glucose metabolism in astrocytes. J. Biol. Chem. 278:5828-5836

Detilleux, J. C. 2004. Neutrophils in the war against Staphylococcus aureus: Predator-prey models to the rescue. J. Dairy Sci. 87:3716-3724.

Detilleux, J. C., M. E. Kehrli Jr., J. R. Stabel, A. E. Freeman, and D. H. Kelley. 1995. Study of immunological dysfunction in periparturient Holstein cattle selected for high and average milk production. Vet. Immunol. Immunopathol. 44:251-267.

Doré, M., D. O. Slauson, M. M. Suyemoto, and N. R. Neilsen. 1990. Calcium mobilization in C5a-stimulated adult and newborn bovine neutrophils. Inflammation 14:71-82.

Dosogne, H., C. Burvenich, A. E. Freeman, M. E. Kehrli Jr., J. C. Detilleux, J. Sulon, J. F. Beckers, and D. Hoeben. 1999. Pregnancy-associated glycoprotein and decreased polymorphonuclear leukocyte function in early post-partum dairy cows. Vet. Immunol. Immunopathol. 67:47-54.

Dosogne, H., F. Vangroenweghe, B. Barrio, P. Rainard, and C. Burvenich. 2001. Decreased number and bactericidal activity against Staphylococcus aureus of the resident cells in milk of dairy cows during early lactation. J. Dairy Res. 68:539-549.

Fejfarová, V., A. Jirkovska, J. Lupinkova, J. Kovar, J. Kalanin, I. Striz, J. Skibova, P. Boucek, and T. Pelikanova. 2006. Effect of acute hyperglycemia and/or hyperinsulinemia on polymorphonuclear functions in healthy subjects. Metabolism 55:811-818.

Festuccia, W. T., P. Blanchard, V. Turcotte, M. Laplante, M. Sariahmetoglu, D. N. Brindley, and Y. Deshaies. 2009. Depot-specific effects of the PPAR agonist rosiglitazone on adipose tissue glucose uptake and metabolism. J. Lipid Res. 50:1185-1194.

Fialkow, L., Y. Wang, and G. P. Downey. 2007. Reactive oxygen and nitrogen species as signaling molecules regulating neutrophil function. Free Radic. Biol. Med. 42:153-164.

Freitas, M., G. Porto, J. L. Lima, and E. Fernandes. 2009. Optimization of experimental settings for the analysis of human neutrophils oxidative burst in vitro. Talanta 78:1476-1483.

Ghanim, H., S. Dhindsa, A. Aljada, A. Chaudhuri, P. Viswanathan, and P. Dandona. 2006. Low-dose rosiglitazone exerts an antiinflammatory effect with an increase in adiponectin independently of free fatty acid fall and insulin sensitization in obese type 2 diabetics. J. Clin. Endocrinol. Metab. 91:3553-3558.

Ghanim, H., R. Garg, A. Aljada, P. Mohanty, Y. Kumbkarni, E. Assian, W. Hamouda, and P. Dandona. 2001. Suppression of nuclear factor-kappaB and stimulation of inhibitor kappaB by troglita- zone: Evidence for an anti-inflammatory effect and a potential antiatherosclerotic effect in the obese. J. Clin. Endocrinol. Metab. 86:1306-1312.

Guidry, A. J., M. J. Paape, and R. E. Pearson. 1976. Effects of parturition and lactation on blood and milk cell concentrations, corticosteroids, and neutrophil phagocytosis in the cow. Am. J. Vet. Res. 37:1195-1200.

Hoeben, D., R. Heyneman, and C. Burvenich. 1997. Elevated levels of beta-hydroxybutyric acid in periparturient cows and in vitro effect on respiratory burst activity of bovine neutrophils. Vet. Immunol. Immunopathol. 58:165-170.

Hoeben, D., E. Monfardini, G. Opsomer, C. Burvenich, H. Dosogne, A. De Kruif, and J. F. Beckers. 2000. Chemiluminescence of bovine polymorphonuclear leucocytes during the periparturient period and relation with metabolic markers and bovine pregnancyassociated glycoprotein. J. Dairy Res. 67:249-259.

Houseknecht, K. L., B. M. Cole, and P. J. Steele. 2002. Peroxisome proliferator-activated receptor gamma (PPARgamma) and its ligands: A review. Domest. Anim. Endocrinol. 22:1-23.

Jiang, C., A. T. Ting, and B. Seed. 1998. PPAR-gamma agonists inhibit production of monocyte inflammatory cytokines. Nature 391:82-86.

Karin, M., and Y. Ben-Neriah. 2000. Phosphorylation meets ubiquitination: The control of NF-[kappa]B activity. Annu. Rev. Immunol. 18:621-663.

Kehrli, M. E. Jr., and J. P. Goff. 1989. Periparturient hypocalcemia in cows: Effects on peripheral blood neutrophil and lymphocyte function. J. Dairy Sci. 72:1188-1196.

Kehrli, M. E. Jr., B. J. Nonnecke, and J. A. Roth. 1989. Alterations in bovine neutrophil function during the periparturient period. Am. J. Vet. Res. 50:207-214.

Kimura, K., T. A. Reinhardt, and J. P. Goff. 2006. Parturition and hypocalcemia blunts calcium signals in immune cells of dairy cattle. J. Dairy Sci. 89:2588-2595.

Kushibiki, S., K. Hodate, H. Shingu, Y. Ueda, M. Shinoda, Y. Mori, T. Itoh, and Y. Yokomizo. 2001. Insulin resistance induced in dairy steers by tumor necrosis factor alpha is partially reversed by 2,4-thiazolidinedione. Domest. Anim. Endocrinol. 21:25-37.

LeBlanc, S. J., K. D. Lissemore, D. F. Kelton, T. F. Duffield, and K. E. Leslie. 2006. Major advances in disease prevention in dairy cattle. J. Dairy Sci. 89:1267-1279.

Lippolis, J. D., B. D. Peterson-Burch, and T. A. Reinhardt. 2006a. Differential expression analysis of proteins from neutrophils in the periparturient period and neutrophils from dexamethasone-treated dairy cows. Vet. Immunol. Immunopathol. 111:149-164.

Lippolis, J. D., T. A. Reinhardt, J. P. Goff, and R. L. Horst. 2006b. Neutrophil extracellular trap formation by bovine neutrophils is not inhibited by milk. Vet. Immunol. Immunopathol. 113:248 255.

Mallard, B. A., J. C. Dekkers, M. J. Ireland, K. E. Leslie, S. Sharif, C. L. Vankampen, L. Wagter, and B. N. Wilkie. 1998. Alteration in immune responsiveness during the peripartum period and its ramification on dairy cow and calf health. J. Dairy Sci. 81:585-595.

Maratou, E., G. Dimitriadis, A. Kollias, E. Boutati, V. Lambadiari, P. Mitrou, and S. A. Raptis. 2007. Glucose transporter expression on the plasma membrane of resting and activated white blood cells. Eur. J. Clin. Invest. 37:282-290.

Marklund, S. L. 1992. Regulation by cytokines of extracellular superoxide dismutase and other superoxide dismutase isozymes in fibroblasts. J. Biol. Chem. 267:6696-6701.

Mehrzad, J., H. Dosogne, E. Meyer, R. Heyneman, and C. Burvenich 2001. Respiratory burst activity of blood and milk neutrophils in dairy cows during different stages of lactation. J. Dairy Res. 68:399-415.

Mehrzad, J., L. Duchateau, S. Pyorala, and C. Burvenich. 2002. Blood and milk neutrophil chemiluminescence and viability in primiparous and pluriparous dairy cows during late pregnancy, around parturition and early lactation. J. Dairy Sci. 85:3268-3276.

Miao, L., and D. K. St. Clair. 2009. Regulation of superoxide dismutase genes: Implications in disease. Free Radic. Biol. Med. $47: 344-356$. 
Nielsen, L., C. M. Rontved, M. O. Nielsen, L. R. Norup, and K. L. Ingvartsen. 2003. Leukocytes from heifers at different ages express insulin and insulin-like growth factor-1 (IGF-1) receptors. Domest. Anim. Endocrinol. 25:231-238.

Okouchi, M., N. Okayama, M. Shimizu, H. Omi, T. Fukutomi, and M. Itoh. 2002. High insulin exacerbates neutrophil-endothelial cell adhesion through endothelial surface expression of intercellular adhesion molecule-1 via activation of protein kinase $\mathrm{C}$ and mitogenactivated protein kinase. Diabetologia 45:556-559.

Paape, M., J. Mehrzad, X. Zhao, J. Detilleux, and C. Burvenich. 2002. Defense of the bovine mammary gland by polymorphonuclear neutrophil leukocytes. J. Mammary Gland Biol. Neoplasia $7: 109-121$.

Paape, M. J., D. D. Bannerman, X. Zhao, and J. W. Lee. 2003. The bovine neutrophil: Structure and function in blood and milk. Vet. Res. 34:597-627.

Rassias, A. J., C. A. Marrin, J. Arruda, P. K. Whalen, M. Beach, and M. P. Yeager. 1999. Insulin infusion improves neutrophil function in diabetic cardiac surgery patients. Anesth. Analg. 88:10111016.

Ricote, M., A. C. Li, T. M. Willson, C. J. Kelly, and C. K. Glass. 1998. The peroxisome proliferator-activated receptor-gamma is a negative regulator of macrophage activation. Nature 391:79-82.

Rinaldi, M., P. Moroni, L. Leino, J. Laihia, M. J. Paape, and D. D. Bannerman. 2006. Effect of cis-urocanic acid on bovine neutrophil generation of reactive oxygen species. J. Dairy Sci. 89:41884201.

Rinaldi, M., P. Moroni, M. J. Paape, and D. D. Bannerman. 2007. Evaluation of assays for the measurement of bovine neutrophil reactive oxygen species. Vet. Immunol. Immunopathol. 115:107125 .

Rutledge, A. C., and K. Adeli. 2007. Fructose and the metabolic syndrome: Pathophysiology and molecular mechanisms. Nutr. Rev. 65:S13-S23.

Saad, A. M., and K. Ostensson. 1990. Flow cytofluorometric studies on the alteration of leukocyte populations in blood and milk during endotoxin-induced mastitis in cows. Am. J. Vet. Res. 51:16031607.

SAS. 2001. User's Guide: Statistics. 8th ed. SAS Inst. Inc., Cary, NC.

Scalia, D., N. Lacetera, U. Bernabucci, K. Demeyere, L. Duchateau, and C. Burvenich. 2006. In vitro effects of nonesterified fatty acids on bovine neutrophils oxidative burst and viability. J. Dairy Sci. 89:147-154.

Shuster, D. E., E. K. Lee, and M. E. Kehrli Jr.. 1996. Bacterial growth, inflammatory cytokine production, and neutrophil recruitment during coliform mastitis in cows within ten days after calving, compared with cows at midlactation. Am. J. Vet. Res. 57:15691575 .
Smith, K. L., S. E. Stebulis, M. R. Waldron, and T. R. Overton. 2007. Prepartum 2,4-thiazolidinedione alters metabolic dynamics and dry matter intake of dairy cows. J. Dairy Sci. 90:3660-3670.

Spagnoli, A., G. L. Spadoni, G. Sesti, D. Del Principe, D. Germani, and B. Boscherini. 1995. Effect of insulin on hydrogen peroxide production by human polymorphonuclear leukocytes. Studies with monoclonal anti-insulin receptor antibodies, and an agonist and an inhibitor of protein kinase C. Horm. Res. 43:286-293.

Stegenga, M. E., S. N. van der Crabben, M. C. Dessing, J. M. Pater, P. S. van den Pangaart, A. F. de Vos, M. W. Tanck, D. Roos, H. P. Sauerwein, and T. van der Poll. 2008. Effect of acute hyperglycaemia and/or hyperinsulinaemia on proinflammatory gene expression, cytokine production and neutrophil function in humans. Diabet. Med. 25:157-164.

Suriyasathaporn, W., A. J. Daemen, E. N. Noordhuizen-Stassen, S. J. Dieleman, M. Nielen, and Y. H. Schukken. 1999. Beta-hydroxybutyrate levels in peripheral blood and ketone bodies supplemented in culture media affect the in vitro chemotaxis of bovine leukocytes. Vet. Immunol. Immunopathol. 68:177-186.

Top, C., S. Yildiz, O. Oncul, T. Qydedi, A. Cevikbas, U. G. Soyogul, and S. Cavuslu. 2007. Phagocytic activity of neutrophils improves over the course of therapy of diabetic foot infections. J. Infect. $55: 369-373$.

USDA. 2008. Dairy 2007 Part II: Changes in the US Dairy Cattle Industry, 1991-2007. USDA-Animal and Plant Health Inspection Service-Veterinary Services, Centers for Epidemiology and Animal Health, Fort Collins, CO.

Vangroenweghe, F., I. Lamote, and C. Burvenich. 2005. Physiology of the periparturient period and its relation to severity of clinical mastitis. Domest. Anim. Endocrinol. 29:283-293.

Walrand, S., C. Guillet, Y. Boirie, and M. P. Vasson. 2004. In vivo evidences that insulin regulates human polymorphonuclear neutrophil functions. J. Leukoc. Biol. 76:1104-1110.

Weber, P. S., S. A. Madsen, G. W. Smith, J. J. Ireland, and J. L. Burton. 2001. Pre-translational regulation of neutrophil L-selectin in glucocorticoid-challenged cattle. Vet. Immunol. Immunopathol. $83: 213-240$.

Wilson, D. J., R. N. Gonzalez, J. Hertl, H. F. Schulte, G. J. Bennett, Y. H. Schukken, and Y. T. Grohn. 2004. Effect of clinical mastitis on the lactation curve: A mixed model estimation using daily milk weights. J. Dairy Sci. 87:2073-2084.

Zhang, B., J. Hirahashi, X. Cullere, and T. N. Mayadas. 2003. Elucidation of molecular events leading to neutrophil apoptosis following phagocytosis: Cross-talk between caspase 8 , reactive oxygen species, and MAPK/ERK activation. J. Biol. Chem. 278:2844328454 . 